UNIVERSIDADE DE BRASÍLIA

PROGRAMA DE PÓS GRADUAÇÃo EM GESTÃo PÚBLICA

MESTRADO PROFISSIONAL EM GESTÃO PÚBLICA

ISABELLA ARAÚJO FIGUEIREDO

INFLUÊNCIA DAS CAPACITAÇÕES NA IMPLEMENTAÇÃO DO PROGRAMA NACIONAL DE ALIMENTAÇÃO ESCOLAR EM MINAS GERAIS 


\section{ISABELLA ARAÚJO FIGUEIREDO}

INFLUÊNCIA DAS CAPACITAÇÕES NA IMPLEMENTAÇÃO DO PROGRAMA NACIONAL DE ALIMENTAÇÃO ESCOLAR EM MINAS GERAIS

\footnotetext{
Dissertação de mestrado profissionalizante apresentada ao Programa de Pós-Graduação em Gestão Pública da Universidade de Brasília - PPGP.

Orientação: Professora Doutora Annita Valléria Calmon Mendes
}

\section{Brasília-DF}


Ficha catalográfica elaborada automaticamente, com os dados fornecidos pelo(a) autor(a)

Araújo Figueiredo, Isabella

INFLUÊNCIA DAS CAPACITAÇÓES NA IMPLEMENTAÇ̃̃O DO

PROGRAMA NACIONAL DE ALIMENTAÇÃO ESCOLAR EM MINAS

GERAIS / Isabella Araújo Figueiredo; orientador

Annita Vallêria Calmon Mendes. -- Brasília, 2017.

$101 \mathrm{p}$.

Dissertação (Mestrado - Mestrado Profissional em Gestão Pública) - - Universidade de Brasília, 2017.

1. Implementação de políticas públicas. 2 . Capacitação de implementadores de políticas públicas 3. Programa Nacional de Alimentação Escolar, I. Calmon Mendes, Annita Vallêria, orient. II, Título. 


\title{
INFLUÊNCIA DAS CAPACITAÇÕES NA IMPLEMENTAÇÃO DO PROGRAMA NACIONAL DE ALIMENTAÇÃO ESCOLAR EM MINAS GERAIS
}

\begin{abstract}
Dissertação de mestrado profissionalizante apresentada ao Programa de Pós-Graduação em Gestão Pública da Universidade de Brasília - PPGP.
\end{abstract}

\begin{abstract}
Professora Doutora Annita Valéria Calmon Mendes
Programa de Pós Graduação em Gestão Pública da Universidade de Brasilia Orientadora
\end{abstract}

\begin{abstract}
$\overline{\text { Professora Doutora Luciana de Oliveira Miranda }}$
Programa de Pós Graduação em Gestão Pública da Universidade de Brasília Examinadora Interna
\end{abstract}

Doutora Leila Giandoni Ollaik

Especialista em Políticas Públicas e Gestão Governamental

Examinadora Externa

Doutor Jonilto Costa Sousa

Programa de Pós Graduação em Gestão Pública da Universidade de Brasília Suplente 


\section{AGRADECIMENTOS}

Agradeço aos meus colegas do FNDE, que colaboraram de alguma forma para a realização deste trabalho. À equipe da Coordenação Geral do Programa Nacional de Alimentação Escolar, nominalmente à Manuelita Brito, Kênia Sampaio, Beatriz Pucci, Karine Santos, Renata Gomes, Priscila Diniz e Déborah Bosco, pela generosidade no compartilhamento de informações e esclarecimento de todas as minhas dúvidas sobre o programa. Aos colegas Luciana Gottshall e Olímpio Soares, pela presteza e disponibilidade. Ao colega Leomir Araújo pelos momentos preciosos de troca de ideias, solidariedade, confiança e "é... não é bem assim" e "cara, isso vai ficar muito legal!". À equipe da Assessoria de Educação Corporativa, pela compreensão das minhas ausências e do meu constante esgotamento, especialmente ao Carlos Fortini, que muitas vezes precisou assumir as responsabilidades do meu trabalho sem poder deixar o dele de lado, sempre me apoiando, sem se queixar. Aos amigos Leonardo Claver, Tayana Machado, Luciana Farias, Márcia Almeida, Estêvão Perpétuo pelo incentivo de sempre.

À minha orientadora, Professora Annita Calmon, pela parceria, paciência e dedicação com que conduziu todo o processo de produção desta dissertação. Aos professores membros da banca, que aceitaram contribuir com este trabalho. Aos meus queridos colegas do curso de Mestrado, pela convivência, companheirismo e apoio em todos os momentos. Aos professores do curso, que, cada um a sua maneira, mostraram os caminhos para a produção de boas discussões e bons trabalhos. A todos os entrevistados, que concordaram em colaborar com esta pesquisa.

Ao marido, Fabiano Maia, pelo amor, respeito e cumplicidade, e principalmente por entender que eu tive que ficar, quando ele precisou ir. Aos meus pais e irmã, pelo carinho constante e compreensão dos períodos que ficaram sem visitas minhas. Aos meus amigos, de 
Brasília e Belo Horizonte, que precisaram dividir com minha dissertação o tempo que antes era só deles. 


\section{RESUMO}

Esta dissertação tem como objetivo investigar como as capacitações dos atores envolvidos no Programa Nacional de Alimentação Escolar (PNAE) influenciam a implementação do programa e se conectam aos objetivos pretendidos por ele em municípios do estado de Minas Gerais. Esse objetivo foi pesquisado à luz da teoria dos burocratas de nível de rua (Lipsky, 2010), considerando a influência do implementador nos resultados da política pública. Para o desenvolvimento da pesquisa, qualitativa e exploratória, o percurso metodológico contou com análise documental e de conteúdo e realização de entrevistas com os implementadores do PNAE - nutricionistas, cozinheiros, diretores, professores e membros do Conselho de Alimentação Escolar (Cae) - em três escolas, cada uma em um município mineiro: Diamantina, Mateus Leme e Monte Carmelo. O intuito das entrevistas foi o de compreender o ponto de vista de cada um dos atores em relação à implementação do programa, levando-se em conta a educação alimentar e nutricional (EAN), a oferta de alimentos e as capacitações realizadas. Por meio dessas diferentes visões, foi possível compreender como se dá a implementação do PNAE nos municípios, seus pontos comuns e divergentes nesse processo. Os resultados obtidos indicam que a interferência do implementador na política pública é irremediável (PRESSMAN, WILDAVSKY, 1984; LIPSKY, 2010). Os cursos de capacitação sobre o programa, cuja oferta não é homogênea para todos os atores, podem alinhar informações e adequar a implementação à política elaborada, mas não se mostraram capazes de inibir a interferência do implementador ou de mudar essencialmente nem as pessoas que atuam no programa, nem os hábitos e cultura regionais. Essa visão bottom-up mostra que os objetivos do PNAE têm sido parcialmente cumpridos e que a principal lacuna percebida é referente à EAN. Nesse caso, é relevante notar que os atores que naturalmente promovem essas ações nas escolas, professores e diretores, não são incluídos nas capacitações, o que reforça a necessidade de ofertas constantes e alinhadas às necessidades dos implementadores. Destaca-se como proposição deste trabalho uma escala de capacitação que pode ser aplicada para dimensionar as lacunas em processos de capacitação sobre o PNAE.

PALAVRAS-CHAVE: implementação de políticas públicas; Programa Nacional de Aimentação Escolar; burocratas de nível de rua. 


\begin{abstract}
This dissertation aims to investigate how the training offred to actors involved in the National School Feeding Program (PNAE) influence the program's implementation and are connected to the objectives intended by it in municipalities in the state of Minas Gerais. This objective was researched having in mind the street-level bureaucrats' theory (Lipsky, 2010), considering the influence of the implementer on the public policy results. For the development of the qualitative and exploratory research, the methodological course included documentary and content analysis and interviews with PNAE implementers - nutritionists, cooks, directors, teachers and members of the School Feeding Council (Cae) - in three schools, each one in a different city: Diamantina, Mateus Leme and Monte Carmelo. The purpose of the interviews was to understand each actor's point of view regarding the implementation of the program, taking into account food and nutrition education (EAN), food supply and training. Through these different views, it was possible to understand how PNAE's implementation in municipalities occurs, as well as its common and divergent points in this process. The results indicate that the implementer's interference in the public policy is irremediable (PRESSMAN, WILDAVSKY, 1984; LIPSKY, 2010). Despite the fact that the training offers are not homogeneous for all actors, the courses can align information and adapt the implementation to the policy elaborated. However, they have not been able to inhibit the implementer's interference or to change essentially neither the people who work in the Program, nor the regional habits and culture. This bottom-up view shows that PNAE's objectives have been partially fulfilled and that the main perceived gap is related to EAN. In this case, it is important to note that the actors who naturally promote these actions in schools, teachers and directors, are not included in the training, which reinforces the need for constant and suitable offers. It is highlighted as proposition of this work a scale of qualification that can be applied to size the gaps in training processes on PNAE.
\end{abstract}

KEY WORDS: public policies' implementation; National School Feeding Program; Street level bureaucrats; training. 


\section{LISTA DE FIGURAS}

Figura 1: Ciclo Anual do PNAE ..................................... 29

Figura 2: Fluxo Cecane ................................................. 39 


\section{LISTA DE QUADROS}

Quadro 1 - Contribuições dos Autores - Políticas Públicas e o Processo de Implementação . 26

Quadro 2- Papéis dos implementadores do PNAE

Quadro 3 - Contribuições dos Autores - Implementação do Programa Nacional de

Alimentação Escolar

Quadro 4 - Contribuições dos Autores - Capacitação dos atores do Programa Nacional de Alimentação Escolar

Quadro 5 - Municípios Selecionados: Número de Habitantes e PIB

Quadro 6 - Matriz de Análise

Quadro 7 - Entrevistados por Município

Quadro 8 - Relação da Primeira Categoria com os Objetivos Específicos Relacionados 62

Quadro 9 - Relação da Segunda Categoria com os Objetivos Específicos Relacionados 67

Quadro 10 - Relação da Terceira Categoria com o Objetivo Específico Relacionado ..... 73

Quadro 11 - Escala de Capacitações 75 


\section{LISTA DE ABREVIATURAS E SIGLAS}

CAE Conselho de Alimentação Escolar

CECANE Centro Colaborador em Alimentação e Nutrição Escolar

CGU Controladoria Geral da União

DF Distrito Federal

EAD Educação a Distância

EAN Educação Alimentar e Nutricional

EEX Entidade Executora

FNDE Fundo Nacional de Desenvolvimento da Educação

FPE Formação pela Escola

IBGE Instituto Brasileiro de Geografia e Estatística

IFES Instituição Federal de Ensino Superior

PNAE Programa Nacional de Alimentação Escolar

PNE Plano Nacional de Educação

SIGECON Sistema de Gestão de Conselhos

SIGPC Sistema de Gestão de Prestação de Contas

SIMEC Sistema Integrado de Monitoramento, Execução e Controle

SNE Sistema Nacional de Educação

TC Termo de Cooperação

TED Termo de Execução Descentralizada

UFOP Universidade Federal de Ouro Preto 


\section{SUMÁRIO}

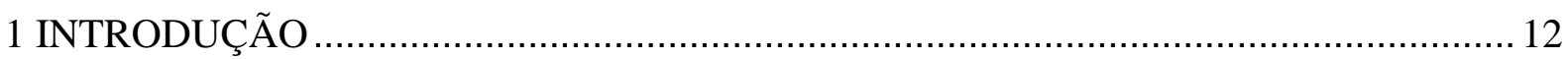

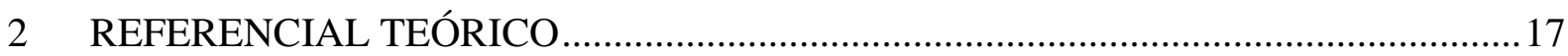

2.1 Políticas Públicas e o Processo de Implementação................................................. 17

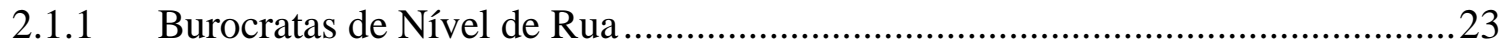

2.2 Implementação do Programa Nacional de Alimentação Escolar...............................27

2.3 Capacitação dos atores do Programa Nacional de Alimentação Escolar....................35

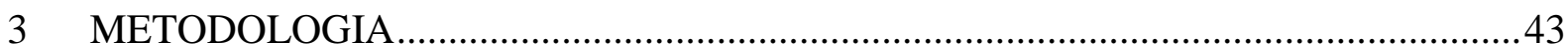

3.1 Análise Exploratória Inicial e Seleção de Casos .................................................. 44

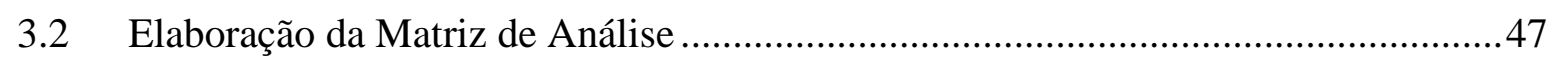

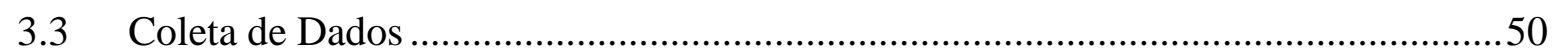

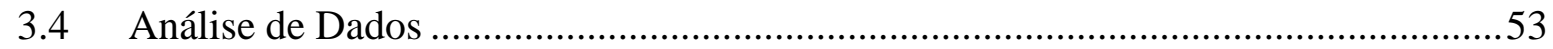

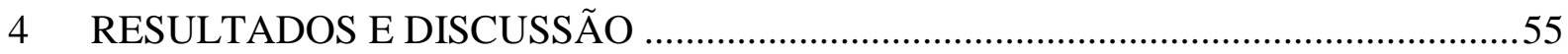

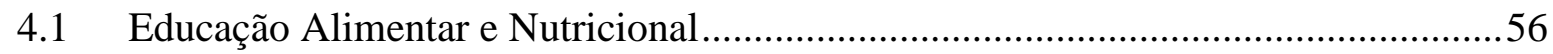

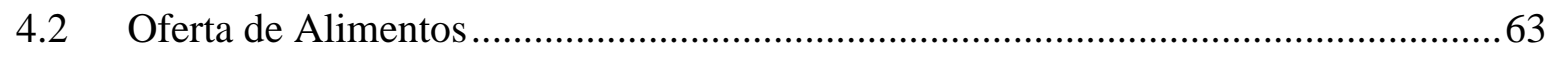

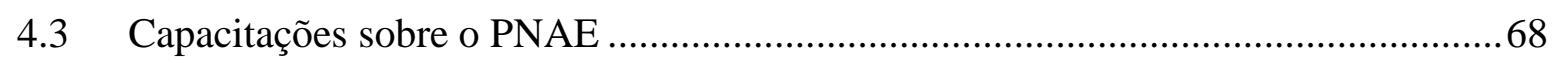

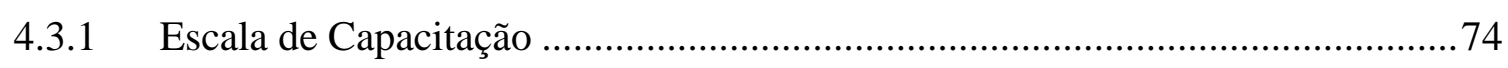

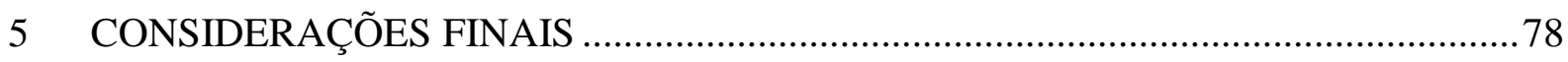

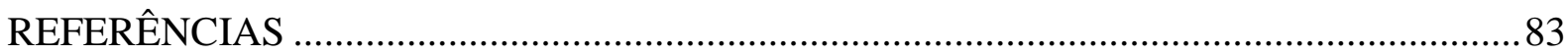

APÊNDICE A - ROTEIRO PARA ENTREVISTAS ….................................................... 90

APÊNDICE B - TERMO DE CONSENTIMENTO ........................................................... 91

ANEXO A - MODELO DE QUESTIONÁRIO DO PNAE NO SIGPC - PREFEITURAS ...92

ANEXO B - MODELO DE QUESTIONÁRIO DO PNAE NO SIGPC - CAE......................97 


\section{INTRODUÇÃO}

O Estado, as sociedades e cidadãos são dinâmicos e passam por mudanças contínuas, inerentes a seu processo de desenvolvimento. Essa vivacidade requer adaptações no modo de compreender as questões públicas, estudá-las, propor soluções, implementá-las. A implementação de políticas públicas, pano de fundo deste trablho, deve acompanhar o tipo de problema enfrentado pela sociedade, os objetivos da política para a solução do problema, os atores envolvidos, os beneficiários diretos e o modo de transferência de recursos para sua viabilização.

Bom exemplo dessa necessidade de adaptação é o Programa Nacional de Alimentação Escolar (PNAE), que completou 61 anos em março de 2016 e continua sendo um dos principais programas da política de educação no Brasil. Criado em 1955 como estratégia para o enfrentamento da fome e da desnutrição no Brasil, problemas graves identificados à época, o programa cresceu e passou a atender a objetivos coerentes com o cenário brasileiro ao longo dos anos. A partir de 2003, com a instituição da estratégia Fome Zero, até os dias atuais, o problema a ser enfrentado pela política passou a englobar não apenas questões relativas à fome, mas à transferência de renda, ao acesso a serviços, à geração de emprego, à inclusão produtiva. Diante disso, o objetivo principal do programa, de acordo com o artigo quarto da Lei no 11.947 (BRASIL, 2009) é

\footnotetext{
contribuir para o crescimento e o desenvolvimento biopsicossocial, a aprendizagem, o rendimento escolar e a formação de hábitos alimentares saudáveis do alunado, por meio de ações de educação alimentar e nutricional e da oferta de refeições que atendam às suas necessidades nutricionais durante o período letivo.
}

Com a mudança do tipo de problema enfrentado e, consequentemente, dos objetivos da política para a solução do problema, é natural que haja envolvimento de diversos atores na implementação do programa. Atualmente, estão envolvidos diretamente com o PNAE 
nutricionistas, conselheiros escolares, gestores escolares, gestores municipais e estaduais, professores e cozinheiros. Os beneficiários do programa hoje são estudantes de toda a rede de educação básica do país matriculados em escolas públicas, filantrópicas e em entidades comunitárias (BRASIL, 2009, 2013). Já os recursos que suplementam a aquisição de alimentos nas escolas públicas brasileiras são repassados a prefeituras e escolas por meio de transferência automática feita pelo Fundo Nacional de Desenvolvimento da Educação (FNDE) (BRASIL, 2009). Essa transferência de recursos vem acompanhada de uma série de exigências legais. Segundo a Lei 11.947 (BRASIL, 2009), são exigências do PNAE: a compra de produtos de agricultura familiar; contratação de nutricionistas para elaboração dos cardápios; inclusão da educação alimentar e nutricional (EAN) nos currículos escolares; atuação dos conselhos de alimentação escolar.

Quando os estudos e discussões sobre políticas públicas chegam à implementação, uma das questões que vêm à tona é a sua efetividade. Saber se o alcance do objetivo da política foi ou está sendo possível é primordial para que se justifique o investimento de recursos e se avance na solução de um problema social previamente identificado ${ }^{1}$. $\mathrm{O}$ tratamento acadêmico sobre a efetividade da implementação de políticas públicas pode se dar por alguns caminhos. Destacam-se dois deles: o que estuda propriamente a avaliação de efetividade da política; e o que considera as medidas de antecipação à implementação, usadas para contribuir para que ela seja feita da melhor forma possível. A abordagem deste trabalho se dará sob a perspectiva desta, focando a oferta de capacitação como meio de auxílio à boa implementação e alcance dos objetivos da política pública. No caso do PNAE, são ofertados cursos de capacitação pelo FNDE, tanto de forma direta, por meio do programa Formação

\footnotetext{
${ }^{1}$ Pesquisa no Portal de Periódicos da Capes (Disponível em: 〈www.periodicos.gov.br〉. Acesso em 24 de outubro de 2016), utilizando o recurso de busca avançada com as palavras chave Implementação e Efetividade, apresentou 98 publicações dos últimos cinco anos que tangenciam esses assuntos. Dessas, 26 são sobre políticas públicas.
} 
pela Escola (FPE), quanto de forma indireta, por meio dos Centros Colaboradores em Alimentação e Nutrição Escolar (Cecanes) com a finalidade de alinhar as informações acerca do PNAE e tornar a implementação mais efetiva, proporcionando aos municípios atingimento dos resultados esperados pelo programa.

A fase de implementação não vinha sendo objeto sistemático de produção acadêmica desde que os estudos sobre o tema tiveram início, na década de 1970, principalmente nos países da América Latina (SAETREN, 2005; OLLAIK, 2012). Apesar de o tema ser pesquisado há alguns anos, a partir da obra de Pressman e Wildavsky (1984), cuja primeira edição foi publicada em 1973, o estudo sobre implementação de políticas públicas é menos recorrente que os estudos sobre formulação, por exemplo. ${ }^{2}$ Sendo assim, além da contribuição direta para os estudos sobre implementação de políticas públicas, esta pesquisa é uma investigação exploratória sobre a implementação, pesquisada sob a ótica das estratégias de capacitação ofertadas aos implementadores do PNAE.

No que tange as capacitações dos atores envolvidos com a implementação do PNAE, elas são fortemente recomendadas por órgãos de controle. Em razão de ser um programa de abrangência nacional, é esperado que o PNAE não tenha uma implementação uniforme em todos os municípios do país, o que pode significar o não atingimento dos objetivos do programa em algumas localidades. Essa suposição pode ser justificada tanto pela inabilidade do implementador em prestar um serviço adequado (LIPSKY, 2010), quanto pelos diferentes problemas que podem ocorrer localmente na fase de implementação de uma política pública (PRESSMAN, WILDAVSKY, 1984). Uma das formas de tentar amenizar essas questões é ofertar capacitação específica para os atores envolvidos na implementação do programa. Com

\footnotetext{
${ }^{2}$ Em busca realizada pelo Portal de Periódicos da Capes em 20 de janeiro de 2016 (Disponível em: <www.periodicos.gov.br>), foram usadas as palavras chave Implementação e Formulação. O resultado dessa busca apresentou 56 publicações sobre implementação, 65 sobre formulação, o que indica preferência dos pesquisadores pela etapa de formulação de políticas públicas.
} 
as capacitações se espera que haja melhor aproveitamento dos recursos repassados para financiar o programa e que os objetivos propostos sejam alcançados. Essa é uma exigência da Controladoria Geral da União (CGU), que entende que as políticas públicas geridas pela União, que envolvam atores diversos nos estados e municípios, devem ser acompanhadas por capacitação para que o programa gere bons resultados, fazendo uso integral dos recursos de forma correta. A controladoria deixa clara sua posição no Relatório de Auditoria Anual de Contas do exercício de 2013 (BRASIL, 2013), publicado integralmente pelo FNDE, com as recomendações do órgão de controle. Nesse documento, a CGU recomenda de forma direta que haja capacitação do pessoal envolvido no PNAE. A contribuição desta pesquisa, portanto, também tem caráter social, dada a importância do tema para instituições públicas brasileiras.

Nesse sentido, esta pesquisa visa investigar como as capacitações dos atores envolvidos no Programa Nacional de Alimentação Escolar influenciam a implementação do programa e se conectam aos objetivos pretendidos por ele em três escolas, cada uma em um município do estado de Minas Gerais. Para isso, a pesquisa foi direcionada para

- $\quad$ descrever como ocorre a implementação do PNAE nos municípios mineiros;

- analisar como a capacitação de nutricionistas, conselheiros, cozinheiros, professores e diretores escolares influencia a implementação do programa;

- investigar o alcance dos objetivos do programa nos municípios selecionados.

Para responder às perguntas de pesquisa e compreender o problema de pesquisa levantado, foi realizado estudo de casos múltiplos em três municípios do estado de Minas Gerais. Para sua realizaçào foi feita pesquisa bibliográfica, pesquisa documental e entrevistas semiestruturadas.

A organização deste trabalho está feita da seguinte forma: referencial teórico, onde está contido todo o embasamento para a realização da pesquisa, passando pelo conceito de políticas públicas e o processo de implementação, a implementação do PNAE e a capacitação 
de seus atores; metodologia, que detalha o percurso necessário para a realização do trabalho; resultados e discussão, onde é apresentado e analisado de fato o produto das entrevistas; considerações finais, que conclui todo o trabalho, apresentando suas limitações e possibilidades de prosseguimento. 


\section{REFERENCIAL TEÓRICO}

Este capítulo introduz o embasamento teórico utilizado nesta pesquisa, apresentando e discutindo trabalhos anteriores que trataram sobre políticas públicas, em geral, e capacitações sobre o Programa Nacional de Alimentação Escolar, em particular. Foi realizado um levantamento da literatura produzida sobre o assunto com a finalidade de fundamentar as respostas ao problema de pesquisa levantado para esta dissertação.

O capítulo está dividido em três seções: na primeira, discute-se o significado de políticas públicas sob o ponto de vista de alguns autores, aprofundando-se principalmente em uma das fases de seu ciclo, que é a implementação. A partir disso, apresenta-se, em uma subseção, a teoria dos burocratas de nível de rua, utilizada para embasamento de toda a pesquisa. Na segunda, é discutida de forma mais específica a implementação do Programa Nacional de Alimentação Escolar, trazendo para o debate produções acadêmicas sobre o tema. Na terceira, são apresentados os principais achados acadêmicos sobre a capacitação dos atores envolvidos na implementação do programa.

\subsection{Políticas Públicas e o Processo de Implementação}

O entendimento sobre o que é política pública é fundamental para se compreender como, por que e para quem os governos e o Estado atuam. Os governos discutem e desenvolvem diversos programas, em diferentes áreas de atuação do Estado. O ponto de convergência desses programas é que eles são considerados políticas públicas. Independentemente de serem políticas de educação, saúde ou transporte, sua base conceitual é a mesma, e todas elas obedecem a um ciclo político, que define a dimensão e os rumos de cada política. Nesse sentido, o desenvolvimento do tema como um campo de estudo partiu de alguns autores que se tornaram os precursores das discussões sobre o assunto, apresentando 
pontos de vista hora divergentes, hora complementares em relação às políticas públicas. Laswell (1936) apresenta o termo "policy analysis" (análise de políticas públicas) por meio de uma discussão sobre ciência política, ressaltando a importância de se definir quem ganha o quê, como, quando e onde. Simon (1997) apresentou em 1945 o conceito de modelo racional de administração, dando ênfase aos processos de tomada de decisão, aos policy makers e à sua racionalidade limitada, que será alcançada quando os interesses da organização se sobrepuserem aos interesses próprios dos policy makers. Contrário à valorização comportamental enfatizada por Simon (1997), Lindblom (1959 e 1979) trata do método incremental, em que as mudanças são feitas aos poucos, passo a passo, e os fatores ambientais são relevantes para a tomada de decisão. Outro pioneiro nas discussões acerca das políticas públicas, Easton (1965) as definiu como sendo um sistema, em que há encadeamento entre as fases de formulação e resultados alcançados.

Com a diversidade de pontos de vista existentes sobre o tema, fica claro que além de não haver uma única definição de políticas públicas, também não se pode dizer que existe a melhor definição (SOUZA, 2007). Compreende-se, contudo, que as definições de políticas públicas podem ter abordagens distintas, mas em geral são uníssonas ao considerar uma visão holística do assunto, apresentando a compreensão de que "o todo é mais importante do que a soma das partes" (SOUZA, 2006, p.25). Para fins deste estudo, adotou-se a definição proposta por Howlett et al. (2013), que compreendem política pública, ou "policy" como aquela que “trata fundamentalmente de atores cercados por restrições que tentam compatibilizar objetivos políticos (policy goals) com meios políticos (policy means), num processo que pode ser caracterizado como "resolução aplicada de problemas."” (HOWLETT et al, 2013, p. 5). Complementando essa ideia, não se pode negligenciar que o processo político de decisão e implementação é uma abordagem inerente às discussões sobre políticas públicas. Para Frey (2000), o processo político é diretamente influenciado pela expectativa que as pessoas têm em 
relação às políticas públicas. Os custos e os benefícios que as pessoas esperam ter com a implementação de uma política pública podem influenciar as decisões e a própria implementação da política.

As abordagens sobre políticas públicas na literatura convergem para uma discussão em que elas, para fins analíticos, são estudadas em etapas (HOWLETT et al 2013; KINGDON, 1995). O ciclo de políticas públicas considera a divisão em etapas e sua sequência cronológica ou concomitante. Para fins desta pesquisa será adotada a definição de Howlet et al (2013), que compreendem o ciclo em cinco estágios: montagem da agenda, formulação, tomada de decisão, implementação e avaliação. Ainda que haja visões diferentes quanto à divisão dos estágios de estudo sobre políticas públicas, a etapa de implementação é comum a todas elas. Segundo Rus Perez (2010), entretanto, há divergência entre os autores quando se fala sobre implementação de políticas públicas. O`Toole (2000, p. 273) defende que a implementação compreende desde o "estabelecimento da política até o seu impacto". Hill e Hupe (2002) defendem que, antes de qualquer coisa, a implementação e a formação política acontecem de forma separada. Linder e Peters (1987) apontam que na literatura geral sobre o assunto, há um entendimento de que a implementação é um estágio entre a formulação e o impacto da política.

A grande dificuldade da delimitação do espaço ocupado por cada uma das etapas no ciclo de políticas públicas se dá pelo fato de elas acontecerem de forma dinâmica. As fases podem ser concomitantes, ou ter sua ordem alterada. Apesar disso, para fins deste estudo considera-se que o espaço ocupado pela implementação no desenvolvimento de políticas públicas, tendo em conta o ciclo de políticas públicas, compreende uma fase entre a formulação e o impacto da política. Trata-se, portanto, da fase em que as ideias discutidas pelos formuladores são colocadas em prática. Segundo Howlett et al (2013, p. 179), "o esforço, os conhecimentos e os recursos empregados para traduzir as decisões políticas em 
ação compreendem o estágio de implementação do ciclo político.” A definição dos autores apresenta a vocação executora da fase de implementação, uma vez que é quando a política começa efetivamente a fazer parte da vida das pessoas, podendo provocar mudanças pela necessidade de alocação de recursos financeiros, designação de pessoas e desenvolvimento de regras de como serão os procedimentos que envolverão a política. $O$ processo de implementação, segundo Bardach (1979), é uma estratégia de interação entre muitos interesses especiais, que têm seus próprios objetivos, que podem ser ou não compatíveis com os objetivos da própria política.

Um dos trabalhos mais importantes sobre implementação de políticas públicas é o estudo de Pressman e Wildasky (1984), que é considerado precursor das investigações sobre o tema. Os autores realizaram estudo de caso sobre a implementação de uma política de criação de empregos na cidade de Oakland, na Califórnia, Estados Unidos, em 1968. Uma das conclusões a que chegaram com esse estudo é que operacionalizar as políticas públicas é muito mais complexo do que parece por conta dos inúmeros problemas que podem ocorrer no nível local. Para os autores, quanto mais tempo a etapa de implementação é exposta a uma cadeia de causalidade, mais numerosas serão as relações entre as causas e os efeitos, e mais complexo será o processo de implementação. Alguns autores como Najam (1995), Oliveira (2006) e Ollaik (2012) consideram que essa foi a primeira geração de estudos sobre implementação de políticas públicas, marcada pelo estudo de caso e pela vontade em desenvolver uma teoria que fosse capaz de generalizações.

O desenvolvimento do campo de estudo continuou com a segunda geração de pesquisas sobre implementação de políticas públicas, que acrescentaram as discussões acerca da implementação top-down, de cima para baixo e bottom-up, de baixo para cima. Segundo Linder e Peters (1987), as abordagens bottom-up e top-down são concepções metodológicas de duas escolas distintas, sendo a européia estudiosa da abordagem bottom-up, e a americana, 
da top-down. Nessa fase se destacam Mazmanian e Sabatier (1983), defendendo que são as autoridades formuladoras das políticas as responsáveis pelo controle da implementação, num modelo top-down. Para os autores, a implementação é a realização de uma decisão política básica, geralmente incorporada em um estatuto ou norma, mas que também pode assumir a forma de ordens executivas ou decisões judiciais. O modelo bottom-up por sua vez foi representado por Lipsky (2010), que acreditava que os atores mais próximos da efetiva implementação são capazes de causar interferências a ela. $\mathrm{O}$ autor criou a expressão streetlevel bureaucrats, ou burocratas de nível de rua, que caracteriza aquelas pessoas que representam o Estado na linha de frente da implementação, sempre em contato direto com o público.

A segunda geração de estudos sobre implementação também foi palco de debates sobre as condições para que haja uma implementação perfeita de qualquer política. Essa foi uma vertente preconizada por Hood (1976) e seguida por Hogwood e Gunn (1984). Para Hood (1976), uma das formas de se analisar os problemas e dificuldades da implementação de políticas públicas é descrever o que seria a implementação perfeita. Hogwood e Gunn (1984) propuseram alguns pontos que consideram relevantes para que a implementação top-down atinja a perfeição, ainda que acreditem que essa não seja uma tarefa possível. As características apontadas pelos autores para se alcançar uma implementação perfeita dizem respeito aos cuidados que devem ser tomados pelos policy makers nessa etapa. Em linhas gerais, esses cuidados envolvem assegurar que os fatores externos não restrinjam as ações necessárias à implementação; que haja tempo e recursos suficientes para o programa; que, quando houver necessidade de que duas ou mais instituições trabalhem em conjunto para a implementação de um programa, que a dependência entre elas seja mínima; que os objetivos do programa estejam claros e que as condições necessárias para alcançá-los persistam por todo o processo de implementação. Como a perspectiva dos autores é top-down, eles 
destacam que o governo central deve usar de sua autoridade para fazer com que os implementadores obedeçam às regras impostas para a implementação. Já para Bardach (1979), a discussão trata do sucesso da implementação, que, segundo o autor, só é possível quando existe amplo acompanhamento de todo o processo. Também abordando o sucesso da implementação, Linder e Peters (1987) defendem que não se pode dizer que uma política foi bem sucedida sem antes se definir de forma clara os critérios de sucesso que serão adotados para avaliar sua implementação. Os autores alegam que verificar se aconteceram mudanças reais nas populações alvo das políticas é apenas uma das formas de se aferir seu sucesso. A descrição de todas essas características é importante para se alcançar uma conclusão irremediável: a de que a implementação perfeita não existe.

A terceira geração de pesquisadores da implementação de políticas públicas vem buscando compreender os sucessos e fracassos da implementação, fazendo uso das teorias e modelos existentes para isso (OLLAIK, 2012; OLIVEIRA, 2006; NAJAM, 1995). Não se discute se um modelo é melhor ou pior que o outro, mas como eles podem ser complementares e apontar para indicadores que ajudem a decifrar os resultados da implementação de políticas públicas.

Pode-se considerar que este trabalho se insere na terceira geração de pesquisa justamente porque buscará compreender as variáveis que influenciam a implementação de uma política pública, sem a ilusão de que existe um modelo infalível de implementação. Para isso, será adotada a ideia de que a implementação é a fase em que os problemas da política são detectados. Diversas são as dificuldades que podem interferir na correta evolução dessa fase, razão pela qual vários autores corroboram a ideia de Hogwood e Gunn (1984) de que não existe implementação perfeita (OLLAIK, MEDEIROS, 2011; LINDER, PETERS, 1987). Para esses autores, além de a perfeição ser inatingível, a implementação de políticas públicas esbarra em um ponto-chave, que é o comportamento humano. A forma com que as pessoas 
compreendem a política e se engajam com sua implementação é fundamental para seu sucesso, mesmo que imperfeito. Linder e Peters (1987) pontuam que o implementador da política é o componente relativo do processo de implementação, já que ele pode alterar seu resultado. Nesse sentido, destaca-se o poder discricionário dos burocratas de nível de rua (LIPSKY, 2010). Existe um paradoxo no processo de implementação, uma vez que ela é efetivamente realizada pelos burocratas de nível de rua, que não tomam as grandes decisões nem assumem as maiores responsabilidades, apesar de terem considerável liberdade e autonomia para atuar. Para este estudo, o conceito de burocratas de nível de rua servirá como norteador, já que se adequa de forma clara à finalidade da pesquisa e às características do PNAE. Esse conceito será aprofundado na subseção a seguir.

\subsubsection{Burocratas de Nível de Rua}

Em 1980, Lipsky (2010) publicou um livro que trata da teoria dos burocratas de nível de rua, concebida originalmente em 1969, como tema de um artigo apresentado no Encontro Anual da Associação Americana de Ciências Políticas ${ }^{3}$. Para o desenvolvimento da teoria, o autor se baseou em servidores públicos que de fato estão em contato com o cidadão, implementando as políticas públicas, efetivamente "entregando" os serviços oferecidos pelo governo, como, por exemplo, professores e policiais. O contato direto, entretanto, não é o que justifica o uso do termo. O entendimento do autor sobre o significado do termo burocratas de nível de rua é o mesmo utilizado neste trabalho. Para ele, o burocrata de nível de rua é o servidor público que não apenas interage diretamente com o cidadão, mas que exerce poder discricionário na execução de seu trabalho. Esse trabalho, essencialmente, não é desempenhado da forma ideal, seguindo à risca todas as determinações para sua implementação, em razão das limitações a que está exposto, como, por exemplo, aquelas

\footnotetext{
${ }^{3}$ As notas do primeiro capítulo do livro de Lipsky (2010, p. 262) apresentam a origem do termo burocratas de nível de rua.
} 
orçamentárias, e as referentes a definições de objetivos claros de cada política.

Quando trata do papel desempenhado pelos burocratas, o autor aponta sua criticidade. Segundo ele, apesar de serem considerados trabalhadores de baixo nível, esses servidores públicos ocupam uma posição crítica por serem os responsáveis pela "entrega” do serviço ao cidadão. Esse papel domina as controvérsias políticas sobre os serviços públicos por duas razões básicas. A primeira é que os debates sobre o escopo e o foco dos serviços públicos passam necessariamente por debates quanto ao escopo e foco dos próprios servidores. $\mathrm{O}$ autor discute sobre o grande número de servidores que atuam como burocratas de nível de rua nos Estados Unidos, em contato direto com os cidadãos; a grande quantidade de recursos alocados para o pagamento de seus salários; o aumento, ao longo dos anos, da quantidade de postos de trabalho voltados para o atendimento de cidadãos, reforçando o escopo dos serviços. Por conta desses fatores, quando se fala em melhorar a prestação de serviços públicos ofertados aos cidadãos, discute-se também o papel do servidor público, que muitas vezes pode parecer maior e mais importante que a própria política.

A segunda razão é que os burocratas têm grande impacto na vida das pessoas, já que eles socializam diretamente com os cidadãos que têm expectativa de usufruir de um serviço prestado pelo governo; eles determinam aqueles que são elegíveis para receber o serviço ou a sanção; eles medeiam aspectos constitucionais da relação entre os cidadãos e o Estado. Para o autor, os cidadãos esperam dos burocratas um tratamento bom e efetivo, ainda que haja limitações em sua tomada de decisão. Em última instância, os burocratas passam, de certa maneira, a formular políticas, já que sua discricionariedade e relativa autonomia podem interferir na forma como a política é implementada (LIPSKY, 2010). Esse cenário pode favorecer, inclusive, o atendimento a objetivos diferentres daqueles idealizados pelos legisladores.

Em relaçào às condições de trabalho dos servidores burocratas de nível de rua, Lipsky 
(2010, p. 27) identifica aquelas às quais esses trabalhadores podem ser submetidos: os recursos são inadequados para o cumprimento das tarefas; há desequilíbrio entre a oferta de e a demanda por serviços; os objetivos das políticas não são claros; o desempenho orientado para a realização de metas é difícil de ser medido; os clientes, ou os cidadãos, não são voluntários. Essas condições são usadas pelo autor para justificar a recorrente inabilidade desses profissionais para a prestação de um serviço apropriado.

Abordando, portanto, desde o papel dos burocratas até suas condições de trabalho, uma das conclusões a que chega o autor é que os burocratas fazem parte de um paradoxo essencial, independentemente das atividades que realizam. Por um lado, seu trabalho costuma ser realizado seguindo o modelo top-down, com burocracias, orientações e legislações que o direcionem para o atingimento dos objetivos da política pública. Por outro lado, o trabalho requer adaptações e improvisações para atender a cada caso, uma vez que a fase de elaboração de uma política não é capaz de prever todos os problemas e peculiaridades de sua execução. Diante desse paradoxo, Lipsky (2010) aponta a dificuldade normalmente encontrada quando se trata de melhorar os serviços públicos prestados, já que a padronização do serviço, cujo intuito é atender de forma igualitária a todos os cidadãos, esbarra, muitas vezes, na necessidade de adaptação e adequação da política aos casos individuais ou imprevistos. 
O quadro a seguir apresenta de forma resumida a contribuição que cada um dos autores citados nesta seção deu para o desenvolvimento da pesquisa.

Quadro 1 - Contribuições dos Autores - Políticas Públicas e o Processo de Implementação

\begin{tabular}{|c|c|c|}
\hline Objetivos da Pesquisa & Autor & Principais Contribuições \\
\hline \multirow{11}{*}{$\begin{array}{l}\text { Embasar teoricamente a } \\
\text { delimitação do objeto de } \\
\text { estudo. }\end{array}$} & $\begin{array}{l}\text { Laswell (1936); Easton } \\
\text { (1965) }\end{array}$ & $\begin{array}{l}\text { Conceitos básicos de políticas } \\
\text { públicas }\end{array}$ \\
\hline & Lindblom (1959) & Formulação de políticas públicas \\
\hline & Simon (1977) & Processos de tomada de decisão \\
\hline & Lindblom (1979) & $\begin{array}{l}\text { Método incremental de políticas } \\
\text { públicas. }\end{array}$ \\
\hline & $\begin{array}{c}\text { Kingdon (1995); Howlet et } \\
\text { al (2013) }\end{array}$ & Ciclo de políticas públicas. \\
\hline & Najam (1995) & $\begin{array}{l}\text { Levantamento de teorias sobre } \\
\text { implementação de políticas } \\
\text { públicas. }\end{array}$ \\
\hline & Frey (2000) & $\begin{array}{l}\text { Conceitos básicos de análise de } \\
\text { políticas públicas. }\end{array}$ \\
\hline & Oliveira (2006) & $\begin{array}{l}\text { Os problemas do planejamento de } \\
\text { políticas públicas e a importância } \\
\text { do processo de implementação. }\end{array}$ \\
\hline & Souza (2006); Souza (2007) & $\begin{array}{l}\text { Revisão de literatura sobre } \\
\text { políticas públicas. }\end{array}$ \\
\hline & Ollaik, Medeiros (2011) & $\begin{array}{l}\text { Levantamento de } \text { teorias sobre } \\
\text { implementação } \\
\text { públicas de políticas } \\
\text { governamentais. }\end{array}$ \\
\hline & Ollaik (2012) & $\begin{array}{l}\text { Implementação comparada de } \\
\text { políticas públicas. }\end{array}$ \\
\hline $\begin{array}{l}\text { Subsidiar a descrição da } \\
\text { implementação do PNAE. }\end{array}$ & $\begin{array}{c}\text { Bardach (1979); } \\
\text { Mazmanian, Sabatier } \\
\text { (1983); Hogwood, Gunn } \\
\text { (1984); Rus Perez (2010); } \\
\text { Hood (1976) }\end{array}$ & $\begin{array}{l}\text { Implementação } \\
\text { públicas. }\end{array}$ \\
\hline $\begin{array}{l}\text { Subsidiar a descrição da } \\
\text { implementação do PNAE; }\end{array}$ & Linder, Peters (1987) & $\begin{array}{l}\text { Sucesso do processo de } \\
\text { implementação. }\end{array}$ \\
\hline $\begin{array}{l}\text { dos atores influencia a } \\
\text { implementação; verificar o } \\
\text { alcance dos objetivos. }\end{array}$ & $\begin{array}{l}\text { O' Toole (2000); Hill, Hupe } \\
\text { (2002); Lipsky (2010) }\end{array}$ & $\begin{array}{l}\text { Implementação de políticas } \\
\text { públicas. }\end{array}$ \\
\hline
\end{tabular}

Fonte: elaborado pela autora. 


\subsection{Implementação do Programa Nacional de Alimentação Escolar}

O PNAE é uma política pública de educação, com caráter social, que visa à oferta de alimentos nas escolas da rede pública de ensino, de forma suplementar. Em 2014 o programa atendeu a 42,2 milhões de alunos (Disponível em: 〈www.fnde.gov.br $>$. Acesso em 24 de outubro de 2016). Assim como toda política pública, suas diretrizes, objetivos e limitações estão previstos em legislação específica. Essa legislação foi usada para identificar alguns pontos importantes do programa.

A Lei $n^{\circ} 11.947$ (BRASIL, 2009) define como sendo alimentação escolar a oferta, durante o período letivo, de todo e qualquer alimento no ambiente da escola. Essa mesma legislação apresenta as diretrizes do programa, que são: o emprego da alimentação saudável e adequada; a inclusão da educação alimentar no processo de ensino; a universalização do atendimento; a participação da comunidade no controle social; o apoio ao desenvolvimento sustentável, incentivando a agricultura familiar e a produção de alimentos em âmbito local; a garantia da segurança alimentar e nutricional dos alunos. As diretrizes do PNAE apontam para um objetivo principal, que é o que se busca alcançar a partir da implementação do programa. De acordo com o artigo quarto da Lei $n^{\circ} 11.947$ (BRASIL, 2009), o programa deve contribuir tanto para o desenvolvimento biopsicossocial dos alunos, quanto para seu rendimento escolar e formação de hábitos alimentares saudáveis.

A definição desse objetivo apresenta algumas pistas sobre o que deve ser levado em consideração quando se realiza um estudo sobre a implementação do PNAE. Deve-se verificar se a oferta de alimentos é realizada de forma correta, atendendo às necessidades nutricionais dos alunos. Outro fator importante é a promoção de ações de educação alimentar e nutricional que estimulem hábitos alimentares saudáveis. Além disso, deve-se considerar se a aprendizagem e rendimento escolar estão sendo desenvolvidos. Em um estudo sobre a 
avaliação da gestão municipal do PNAE nos maiores municípios de Santa Catarina, Gabriel et al (2014, p. 1734) destacam pontos de atenção quando se trata da implementação do programa. Os autores apontam que

o gestor deve garantir o acesso universal, equânime, regular e contínuo à alimentação saudável; apoiar o desenvolvimento sustentável e o controle social; promover o resgate dos hábitos alimentares regionais; planejar e monitorar as ações de oferta de alimentação e as ações de educação alimentar e nutricional.

Para se chegar a esses apontamentos, é preciso compreender de que forma a implementação do programa está prevista atualmente. Levando-se em conta os aspectos práticos, existe uma sequência lógica de ações do programa desde o repasse dos recursos até a distribuição das refeições nas escolas, desde o planejamento até a prestação de contas. Esse ciclo, que acontece anualmente e respeita a legislação do programa (BRASIL, 2009, 2013), reflete, de maneira resumida, os processos adotados em sua implementação. Ele foi representado a seguir para ilustrar melhor todas as etapas. 
Figura 1: Ciclo Anual do PNAE

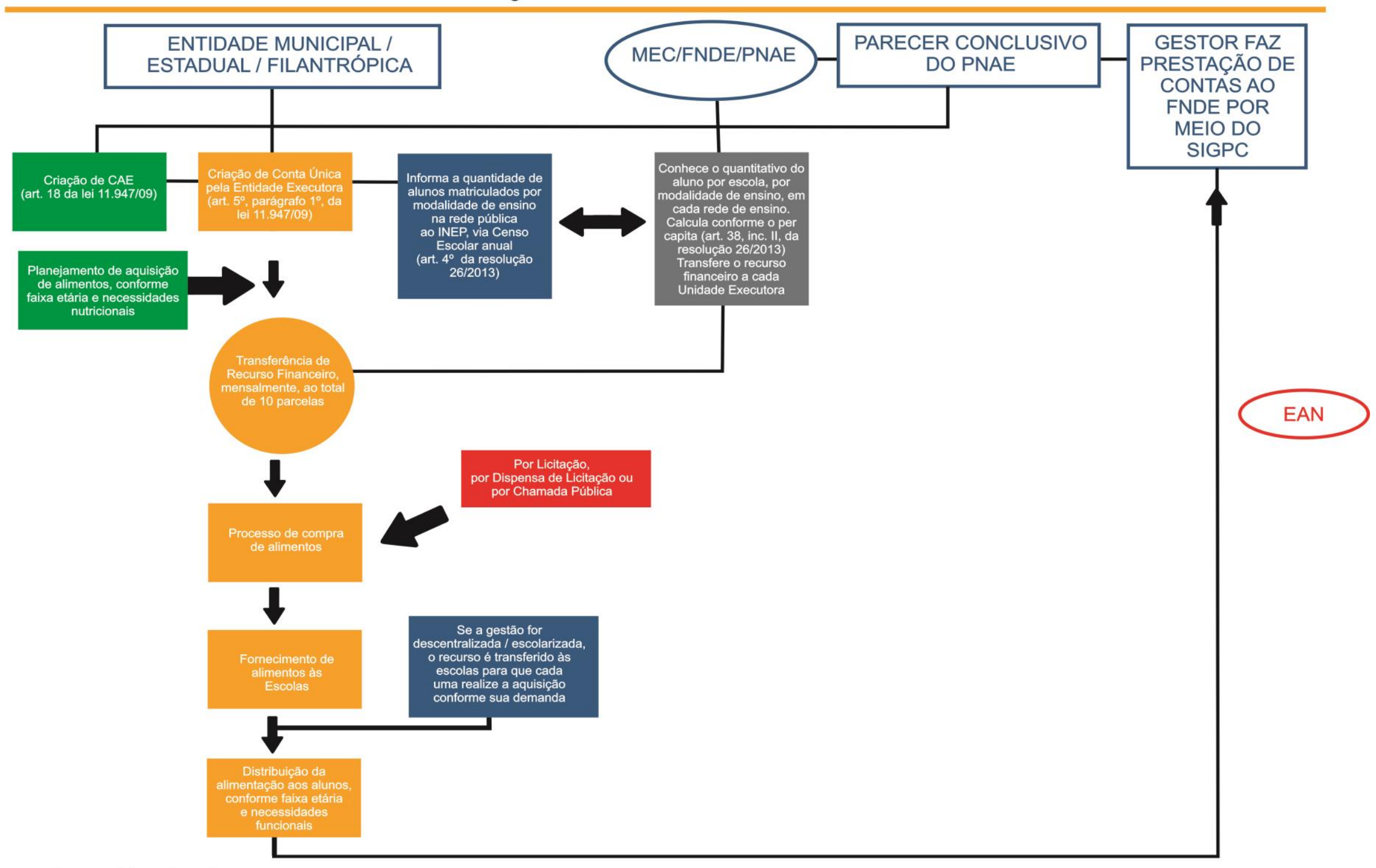

Fonte: elaborado pela autora 
O ciclo tem início com três providências que devem ser tomadas por estados, municípios e Distrito Federal (DF). Essas entidades devem constituir seus Conselhos de Alimentação Escolar (Cae), "órgãos colegiados de caráter fiscalizador, permanente, deliberativo e de assessoramento" (BRASIL, 2009); criar a conta corrente específica para o recebimento dos recursos (BRASIL, 2009); informar, por meio do Censo Escolar, a quantidade de alunos matriculados por modalidade de ensino na rede pública (BRASIL, 2013), já que esse número subsidiará os cálculos dos valores repassados pelo FNDE. Concomitantemente a essas providências, estados, municípios e o DF, denominados entidades executoras para fins do programa, iniciam o planejamento da aquisição de alimentos conforme a faixa etária e necessidades nutricionais dos alunos. Nessa etapa, é imprescindível a participação de nutricionistas. Os recursos financeiros, então, são repassados mensalmente à conta específica de cada entidade executora. As transferências são feitas em dez parcelas, para que seja possível cobrir os dias letivos anuais. A partir da transferência do recurso, dá-se início ao processo de compra de alimentos, que pode ser feita por licitação, dispensa de licitação ou chamada pública. As duas primeiras modalidades de compra são regidas pela chamada Lei de Licitação, nº 8.666 (BRASIL, 1993). A chamada pública, definida pela Resolução CD/FNDE n 26 (BRASIL, 2013), será usada sempre que a entidade executora optar pela dispensa de licitação. Essa modalidade desburocratiza as compras, tornando o processo mais célere. Por meio da chamada pública, são selecionadas propostas para a aquisição de alimentos provenientes da agricultura familiar ou de empreendedores familiares rurais (BRASIL, 2013). Os conselheiros do Cae devem acompanhar esse andamento, para exercerem o controle social no processo das compras. Com a conclusão dos processos administrativos para as compras, os alimentos são efetivamente destinados às escolas e distribuídos aos alunos, conforme sua faixa etária e necessidades nutricionais. A partir daí, as refeições devem ser preparadas por cozinheiros treinados, com o acompanhamento de 
nutricionistas. Para fechamento do ciclo, os gestores das entidades executoras precisam prestar contas ao FNDE dos recursos federais repassados para a compra de alimentos. Essas contas devem ser acompanhadas de perto pelos conselheiros do Cae, que emitem parecer obrigatório e conclusivo sobre elas. A não prestação de contas ou sua reprovação impedem o repasse de recursos federais no ano subsequente a seu julgamento.

Destaca-se que a promoção de ações de educação alimentar e nutricional que estimulem hábitos alimentares saudáveis podem acontecer a qualquer momento, razão pela qual está deslocada do ciclo do programa.

É importante ressaltar que as transferências feitas pelo governo federal a estados, municípios e DF têm caráter suplementar, ou seja, têm a finalidade de complementar os recursos destinados por estados, municípios e DF à merenda escolar (BRASIL, 1988). É interessante notar que, apesar de a transferência ter a intenção de suplementar, a política não é descentralizada. Pode-se dizer que a política é nacional, formulada sob a ótica top-down, uma vez que a legislação do programa é centralizada, e a discricionariedade das entidades executoras no que diz respeito ao cumprimento das leis e ao recebimento dos recursos é bastante limitada. Por outro lado, a implementação não é realizada pelo governo central, mas pelos agentes nos estados, municípios e DF. Nesse sentido, ainda que o cumprimento da legislação obedeça a leis e resoluções nacionais, existe certa liberdade dos agentes na implementação, como, por exemplo, a adequação dos cardápios às especificidades regionais, caracterizando uma perspectiva bottom-up. Lima e Medeiros (2012) pontuam que a formulação da política no Brasil é normalmente centralizada e com tendência homogeneizadora, contrastando com sua implementação, que é heterogênea, variando de acordo com a localidade. O PNAE se enquadra nessa descrição e, portanto, pode ser visto como uma política híbrida, em que as visões top-down e bottom-up coexistem. Como o foco 
deste estudo é a implementação, é natural que a perspectiva bottom-up receba mais destaque, pela natureza do programa aqui descrita.

A forma de implementação do programa pode ser explicada pela dinâmica do federalismo brasileiro, em que os entes têm certa autonomia e muitas responsabilidades. No caso específico do federalismo visto sob a ótica da educação, existem algumas atribuições dos municípios, outras dos estados e DF, e também da União. Abicalil (2012) defende que o Sistema Nacional de Educação (SNE) ainda precisa se fortalecer e isso poderá ser alcançado por meio do Plano Nacional de Educação (PNE), que deverá definir as atribuições de cada ente no desenvolvimento do sistema nacional. Entretanto, mesmo sem a efetividade do plano, o direito público subjetivo e a obrigatoriedade na educação básica se expandiram ao longo do tempo, criando obrigações para estados, DF e municípios. Isso demonstra a dificuldade dos governos em alinhar e direcionar o rumo de certas políticas e definir o que pode ser centralizado e o que deve ser descentralizado, esbarrando na questão do federalismo brasileiro.

Outro ponto importante a ser considerado para a implementação de uma política pública, e no caso do PNAE não é diferente, foi apresentado por Ollaik e Medeiros (2011), que afirmam que o comportamento humano é decisivo para a implementação de uma política pública. Belik e Chaim (2009), avaliando o perfil da gestão pública municipal do PNAE de prefeituras inscritas no Prêmio Gestor Eficiente da Merenda Escolar, afirmam que a gestão do PNAE não é única e se adapta ao contexto de cada localidade. No entanto, os autores avaliam que o perfil das prefeituras vencedoras do referido prêmio indica que existe um fator primordial para o sucesso da implementação do programa, que é "a participação social, seja por meio da atuação ativa do Conselho de Alimentação Escolar, pelo envolvimento de pais de alunos, professores e merendeiras, ou pela inclusão de produtores locais no processo de aquisição de alimentos" (2009, p. 606). No caso do envolvimento dos pais, destaca-se 
principalmente a questão da formação de hábitos alimentares saudáveis, que se refletem no comportamento da criança na escola, influenciando de forma direta suas escolhas alimentares (KNEIPP C. et al, 2015; CARDOSO et al, 2015; SAMPAIO et al, 2013; CHUPROSKI et al, 2012).

A importância do fator humano na implementação da política retoma o conceito de burocratas de nível de rua (LIPSKY, 2010) e torna necessária uma breve descrição dos papéis de cada um dos atores envolvidos no ciclo do PNAE nos municípios brasileiros. Apesar de a Resolução $\mathrm{n}^{\circ} 26$ (BRASIL, 2013) definir como participantes do programa o FNDE, as entidades executoras (estados, municípios, DF e escolas federais), o Cae e as unidades executoras (entidades privadas sem fins lucrativos), para este estudo é preciso compreender quem são os atores que efetivamente participam ativamente do programa. Na verdade, faz-se aqui a personificação das entidades participantes da implementação do PNAE. 
Quadro 2- Papéis dos implementadores do PNAE

\begin{tabular}{|c|c|}
\hline Ator & Papel \\
\hline Prefeito(a) & $\begin{array}{l}\text { Figura política do município, é responsável pela gestão do recurso, desde seu } \\
\text { recebimento até sua prestação de contas; pela elaboração do relatório anual de } \\
\text { gestão do PNAE; por garantir o acesso dos alunos à alimentação; por oferecer } \\
\text { condições de trabalho suficientes e adequadas aos nutricionistas e conselheiros; } \\
\text { pelo cumprimento das normas do programa. }\end{array}$ \\
\hline $\begin{array}{l}\text { Dirigente } \\
\text { Municipal de } \\
\text { Educação }\end{array}$ & $\begin{array}{l}\text { Responsável pela promoção e implementação das ações de educação alimentar e } \\
\text { nutricional; pela estrutura física das escolas; pelos recursos humanos da unidade } \\
\text { de alimentação escolar; por assegurar a oferta de alimentos em conformidade com } \\
\text { as necessidades nutricionais do alunado. }\end{array}$ \\
\hline $\begin{array}{l}\text { Conselheiro(a) do } \\
\text { Cae }\end{array}$ & $\begin{array}{l}\text { Responsável por acompanhar o cumprimento das diretrizes do programa; } \\
\text { acompanhar e fiscalizar a aplicação dos recursos destinados à alimentação escolar; } \\
\text { zelar pela qualidade dos alimentos oferecidos e pela aceitabilidade dos cardápios; } \\
\text { analisar a prestação de contas do gestor; emitir parecer conclusivo do relatório de } \\
\text { gestão anual do PNAE; comunicar qualquer irregularidade identificada na } \\
\text { implementação do programa aos órgãos competentes; fornecer informações sobre } \\
\text { o acompanhamento do programa, sempre que solicitado; elaborar o regimento } \\
\text { interno do Cae; elaborar plano de ação do acompanhamento do PNAE nas escolas } \\
\text { e enviar à entidade executora. }\end{array}$ \\
\hline Nutricionista & $\begin{array}{l}\text { Responsável técnico por coordenar das ações de alimentação escolar; realizar } \\
\text { diagnóstico e acompanhamento do estado nutricional dos alunos; planejar, } \\
\text { elaborar, acompanhar e avaliar o cardápio; acompanhar desde a aquisição até o } \\
\text { preparo, distribuição e consumo das refeições, definir o horário e tipo de alimento } \\
\text { oferecido em cada refeição. }\end{array}$ \\
\hline Diretor(a) Escolar & $\begin{array}{l}\text { Coordenar e realizar, em conjunto com o (a) nutricionista, ações de educação } \\
\text { alimentar e nutricional. }\end{array}$ \\
\hline $\begin{array}{l}\text { Coordenador(a) } \\
\text { Pedagógico(a) e } \\
\text { Professor(a) }\end{array}$ & Promover as ações de educação alimentar e nutricional. \\
\hline Cozinheiro(a) & $\begin{array}{c}\text { Preparar as refeições de acordo com o cardápio desenvolvido pelo (a) } \\
\text { nutricionista. }\end{array}$ \\
\hline
\end{tabular}

Fonte: elaborado pela autora com base na Resolução n 26 (BRASIL, 2013) e na Lei n ${ }^{\circ} 11.947$ (BRASIL, 2009). 
O quadro 3 apresenta de forma resumida a contribuição de cada um dos autores para o desenvolvimento desta pesquisa.

\begin{tabular}{|c|c|c|}
\hline Objetivos da Pesquisa & Autor & Principais Contribuições \\
\hline $\begin{array}{l}\text { Subsidiar a descrição da } \\
\text { implementação do PNAE; } \\
\text { analisar como a capacitação } \\
\text { dos atores influencia a } \\
\text { implementação; verificar o } \\
\text { alcance dos objetivos. }\end{array}$ & $\begin{array}{l}\text { Belik, Chaim (2009); } \\
\text { Gabriel et al (2014) }\end{array}$ & $\begin{array}{l}\text { Avaliação da gestão municipal do } \\
\text { PNAE }\end{array}$ \\
\hline \multirow{2}{*}{$\begin{array}{l}\text { Subsidiar a descrição da } \\
\text { implementação do PNAE; } \\
\text { verificar o alcance dos } \\
\text { objetivos. }\end{array}$} & $\begin{array}{c}\text { Chuproski et al (2012); } \\
\text { Sampaio et al (2013); } \\
\text { Cardoso et al (2015); Kneipp } \\
\text { et al (2015) }\end{array}$ & $\begin{array}{l}\text { Influência da família na prática } \\
\text { alimentar. }\end{array}$ \\
\hline & Abicalil (2012) & $\begin{array}{l}\text { Discussão sobre o federalismo } \\
\text { brasileiro e a educação básica no } \\
\text { país. }\end{array}$ \\
\hline
\end{tabular}

Fonte: elaborado pela autora.

\subsection{Capacitação dos atores do Programa Nacional de Alimentação Escolar (PNAE)}

A natureza do FNDE, que é um fundo que financia os programas educacionais no Brasil, é a assistência financeira. Entretanto, a prestação de assistência técnica faz parte da missão da autarquia (Disponível em: 〈wwww.fnde.gov.br〉. Acesso em 25 de janeiro de 2016). A instituição é responsável por programas finalísticos de educação, sendo o PNAE um deles. Em adequação aos objetivos estratégicos do FNDE, o artigo 16 da Lei $n^{\circ} 11.947$ (BRASIL, 2009) descreve suas atribuições enquanto autarquia responsável pela coordenação nacional do PNAE:

V - prestar orientações técnicas gerais aos Estados, ao Distrito Federal e aos Municípios para o bom desempenho do PNAE; VI - cooperar no processo de capacitação dos recursos humanos envolvidos na execução do PNAE e no controle social. 
Visando atender tanto às determinações legais quanto às estratégicas, o FNDE utiliza alguns recursos fundamentais para a prestação de assistência técnica. Dois deles se destacam no contexto do PNAE: o Programa Formação pela Escola e os Cecanes.

O Programa Formação pela Escola faz parte do rol de ações do FNDE. Trata-se de programa de educação a distância (EAD) que tem como objetivo contribuir para melhorar a qualidade da gestão dos recursos repassados pelo FNDE bem como fortalecer o controle social. O programa conta com a oferta de dez cursos, sendo oito específicos sobre programas financiados diretamente pela autarquia. O público alvo dos cursos ofertados pelo programa são os profissionais de ensino, técnicos e gestores públicos municipais e estaduais, membros da comunidade escolar e cidadãos em geral (Disponível em: 〈www.fnde.gov.br〉. Acesso em 25 de janeiro de 2016). O programa é estruturado em rede, com representantes em todos os estados brasileiros. Para fins deste estudo, serão considerados os cursos do PNAE e de Controle Social para Conselheiros.

O curso do PNAE tem carga horária de 60 horas, é acompanhado por um tutor e acontece integralmente a distância, pela plataforma Moodle. O curso tem como objetivo fundamentar a compreensão do cursista quanto à atuação eficiente e eficaz na operacionalização do programa, no seu controle social e acompanhamento. Pedagogicamente, o curso está dividido em sete unidades, quais sejam: I. Alimentação escolar: um dos fundamentos para uma educação de qualidade; II. Conhecendo o PNAE; III. Alimentação e nutrição; IV. Gestão e operacionalização do PNAE; V. Agricultura Familiar; VI. A Prestação de Contas no âmbito do PNAE; VII. Conselho de Alimentação Escolar (Cae) (Disponível em: <www.fnde.gov.br $>$. Acesso em 28 de janeiro de 2016).

O curso de Controle Social para Conselheiros tem carga horária de 60 horas, é acompanhado por um tutor e também acontece integralmente a distância, pela plataforma 
Moodle. Os objetivos do curso são a contribuição para que o cursista identifique os conselhos sociais como representantes legítimos da sociedade, capazes de supervisionar e avaliar as decisões e ações administrativas; e compreender a atuação legal dos conselhos no acompanhamento das políticas públicas de educação. Cabe esclarecer que o curso não foi desenvolvido apenas para os conselheiros do Cae, mas para quaisquer conselheiros dos programas finalísticos do FNDE. O curso está organizado em sete unidades: I. A participação cidadã e o controle social; II. Conselhos no âmbito da política educacional; III. O Cae e o controle social do PNAE; IV. O Cacs e o controle social do Fundeb; V. As outras responsabilidades do Cacs Fundeb; VI. O acompanhamento de outras ações do FNDE; VII. Conselheiros trabalhando: sistemas informatizados e ferramentas de apoio (Disponível em: <www.fnde.gov.br $>$. Acesso em 28 de janeiro de 2016).

A oferta de cursos do FPE é feita integralmente em EAD desde 2006. Os cursos a distância são usualmente destinados àqueles que precisam de atualização e capacitação, mas que têm dificuldades de frequentar cursos tradicionais, com local e hora marcada. Para Moore e Kearsgley (2008), é crescente a quantidade de pessoas que têm acesso a mais e melhores recursos de aprendizado e isso se deve, em grande medida, à EAD. A modalidade tem utilizado recursos tecnológicos que apresentam a possibilidade de alcançar um grande número de pessoas ao mesmo tempo. Pelissoli e Loyolla (2004) defendem que, além dos computadores, existe um movimento - Mobile Learning (M-Learning) - que visa garantir ainda mais mobilidade aos estudantes, propondo a utilização de dispositivos móveis e portáteis, como telefones celulares e tablets. Nesse sentido, a necessidade de ampliar a quantidade de pessoas capacitadas vai ao encontro do desenvolvimento tecnológico para os cursos em EAD.

Além do FPE, a prestação de assistência técnica aos atores do PNAE se dá por meio dos Cecanes. Os Cecanes são unidades de referência em alimentação e nutrição escolar, 
criados para desenvolver ações de interesse e necessidade do PNAE. Esses centros de colaboração são oriundos de parceria entre o FNDE e as Instituições Federais de Ensino Superior (Ifes) para o desenvolvimento de pesquisas, atividades relacionadas ao ensino e extensão. A parceria pode ocorrer por meio da celebração de Termos de Execução Descentralizada (Ted) ou de Termos de Cooperação (TC) a serem desenvolvidos a partir de planos de trabalho. Para que as Ifes consigam manter estrutura mínima e equipe para execução das atividades nas áreas definidas pelo FNDE, a autarquia realiza descentralização de créditos orçamentários e repasse de recursos financeiros (Disponível em: <www.fnde.gov.br $>$. Acesso em 26 de janeiro de 2016). Para que a parceria fosse possível, em 2013 o FNDE publicou um edital para a habilitação de Ifes como Cecanes. Para serem habilitadas, além de manifestarem interesse em realizar ações de pesquisa, ensino e extensão sobre o PNAE, essas instituições apresentaram propostas e planos de trabalho que foram avaliados pelo FNDE, responsável pela habilitação (BRASIL, 2013. Disponível em: <www.fnde.gov.br>. Acesso em 02 de fevereiro de 2016). Após a habilitação, a Ifes se torna apta a ser um Cecane, mas não existe nenhuma obrigação de celebração de parceria com as instituições habilitadas. Para que a parceria se materialize é necessário que haja disponibilidade orçamentária e que seja conveniente para o FNDE (Disponível em: <www.fnde.gov.br> . Acesso em 26 de janeiro de 2016). O fluxo a seguir apresenta o processo. 
Figura 2: Fluxo Cecane

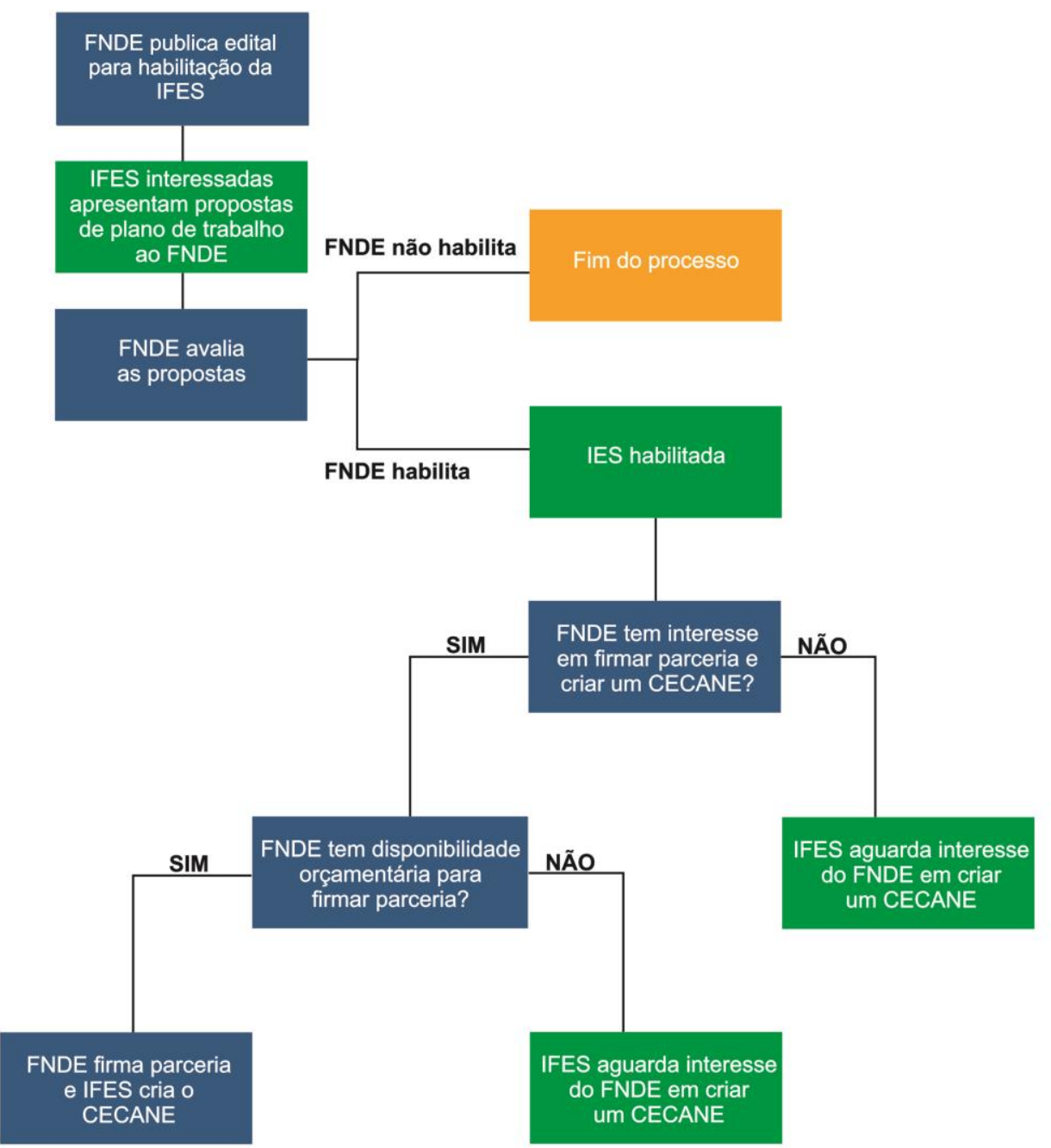

Fonte: Elaborado pela autora 
Estão habilitadas 41 Ifes, e em 2015 havia nove Cecanes ativos, vinculados a universidades federais em Brasília, Minas Gerais, Pará, Bahia, São Paulo, Rio Grande do Norte, Paraná, Santa Catarina e Rio Grande do Sul (Disponível em: 〈www.fnde.gov.br〉. Acesso em 26 de janeiro de 2016). Os Cecanes oferecem cursos específicos de educação alimentar e nutricional, mas o foco de cada trabalho, como ele vai acontecer e para quem ele será direcionado, depende das necessidades de cada estado. Os planos de trabalho de cada instituição são, portanto, customizados de acordo com as peculiaridades de cada localidade e as necessidades identificadas pelo FNDE (Disponível em: 〈www.fnde.gov.br>. Acesso em 26 de janeiro de 2016). Para este estudo, serão utilizados os relatórios de trabalho do Cecane ativo em Minas Gerais, na Universidade Federal de Ouro Preto (UFOP).

Alguns trabalhos que tratam da capacitação dos atores envolvidos no PNAE apontam tanto as limitações quanto os pontos positivos dos desdobramentos das formações e capacitações oferecidas pelo FNDE ou por Cecanes. Em seu trabalho sobre o Prêmio Gestor Eficiente da Merenda Escolar, Belik e Chaim (2009) identificaram que os municípios concorrentes voltavam suas capacitações principalmente às merendeiras, que manipulam diretamente os alimentos e cujo trabalho está inserido na implementação do programa. Leite et al (2011), em trabalho sobre a formação de merendeiras na Bahia, identificaram a necessidade de construir uma proposta participativa de formação, em que essas profissionais pudessem opinar sobre a estruturação do curso. Bandeira (2012), em trabalho desenvolvido exclusivamente com conselheiros do PNAE, também concluiu que o planejamento adequado das formações oferecidas aos conselheiros depende de construção participativa por meio da identificação de suas reais necessidades. A autora acrescenta ainda a necessidade de fazer o levantamento do perfil sociodemográfico desses atores. Honório e Batista (2015), em seu estudo sobre a percepção dos nutricionistas da alimentação escolar sobre sua própria formação, concluíram que esses profissionais não estão, em sua maioria, preparados para 
atuar na alimentação escolar, seja pela especificidade da legislação do programa, seja pela quantidade de atribuições regulamentadas que eles devem exercer. Sendo assim, as autoras julgam necessária a educação permanente desses profissionais para atuação no PNAE. Scarparo et al (2013), também estudando a formação dos profissionais de nutrição que atuam no PNAE, identificaram a necessidade de se estabelecer processo contínuo de formação não apenas dos nutricionistas, como também de outros atores que atuam no programa. Santos et al (2013, p. 999) reforçam a ideia da continuidade argumentando em sua pesquisa sobre a formação de coordenadores pedagógicos em alimentação escolar que "a sensibilização alcançada pode ser fragilizada no retorno dos atores ao seu cotidiano de trabalho, por falta de uma formação permanente."

Apresenta-se aqui um quadro resumo relacionando a contribuição dos autores desta seção para o desenvolvimento da pesquisa. 
Quadro 4 - Contribuições dos Autores - Capacitação dos atores do Programa Nacional de Alimentação Escolar

\begin{tabular}{|c|c|c|}
\hline Objetivos da Pesquisa & Autor & Principais Contribuições \\
\hline \multirow{7}{*}{$\begin{array}{c}\text { Analisar como a } \\
\text { capacitação dos atores } \\
\text { influencia a } \\
\text { implementação; verificar } \\
\text { o alcance dos objetivos. }\end{array}$} & Pelissoli, Loyolla (2004) & $\begin{array}{l}\text { Dispositivos e cenários para } \\
\text { aprendizagem a distância. }\end{array}$ \\
\hline & Moore, Kearsgley (2008) & Desafios da educação a distância \\
\hline & Leite et al (2011) & $\begin{array}{l}\text { Proposta metodológica para a formação } \\
\text { de merendeiras em escolas atendidas } \\
\text { pelo PNAE. }\end{array}$ \\
\hline & Bandeira (2012) & $\begin{array}{l}\text { Elaboração, aplicação e avaliação de } \\
\text { um curso de formação a distância para } \\
\text { conselheiros de alimentação escolar. }\end{array}$ \\
\hline & Santos et al (2013) & $\begin{array}{l}\text { Limitações da multiplicação do } \\
\text { conhecimento no campo de trabalho de } \\
\text { coordenadores pedagógicos } \\
\text { capacitados sobre alimentação escolar. }\end{array}$ \\
\hline & Scarparo et al (2013) & $\begin{array}{llr}\begin{array}{l}\text { Avaliação da } \\
\text { capacitações }\end{array} & \begin{array}{c}\text { efetividade } \\
\text { oferecidas }\end{array} & \text { de } \\
\text { nutricionistas por Cecane. } & & \text { aos }\end{array}$ \\
\hline & Honório, Batista (2015) & $\begin{array}{l}\text { Percepções e demandas dos } \\
\text { nutricionistas atuantes na alimentação } \\
\text { escolar sobre sua formação. }\end{array}$ \\
\hline
\end{tabular}

Fonte: elaborado pela autora.

Este capítulo expôs o embasamento teórico utilizado na pesquisa. A seguir será apresentada a metodologia utilizada para unir a teoria estudada aos resultados encontrados na fase de coleta de dados. 


\section{METODOLOGIA}

Este capítulo apresenta a metodologia utilizada para o alcance das respostas ao problema de pesquisa proposto: como as capacitações dos atores envolvidos no Programa Nacional de Alimentação Escolar influenciam a implementação do programa e se conectam aos objetivos pretendidos por ele em municípios do estado de Minas Gerais. Trata-se, portanto, de pesquisa qualitativa, exploratória, com análise documental e de conteúdo e realização de entrevistas em três municípios do estado de Minas Gerais.

O estudo sobre a implementação de políticas públicas trata da forma como os implementadores compreendem e executam os objetivos de determinada política, o que indica não apenas o caráter executor dessa fase, mas também sua imprescindível flexibilidade. Segundo Yin (1994), os estudos de caso evolvem questionamentos sobre o como e o porquê dos fenômenos, que devem ser contemporâneos e com baixas possibilidades de serem controlados pelo pesquisador. Sendo assim, esse cenário sugere a investigação por meio de estudo de casos múltiplos, estratégia adotada nesta pesquisa.

O capítulo foi dividido em quatro seções, com base nos procedimentos adotados para a organização e estruturação da pesquisa. Esses procedimentos foram a análise exploratória inicial e seleção dos casos; elaboração da matriz de análise; coleta de dados; análise dos dados. 


\subsection{Análise Exploratória Inicial e Seleção de Casos}

Após a definição do tema de pesquisa - implementação do PNAE e capacitações sobre o programa - foi feita leitura flutuante (BARDIN, 1977) de toda a legislação e documentação que envolve o programa bem como de livros e artigos que tratam sobre o tema pesquisado.

A escassez de estudos voltados para as capacitações sobre o PNAE e o alcance dos objetivos do programa caracterizam a pesquisa como exploratória, o que torna a análise inicial de conteúdo imprescindível para o desenvolvimento da pesquisa. No caso deste trabalho, antes da análise de qualquer documento, definiu-se a população da amostra do estudo de caso: o estado de Minas Gerais. A população foi definida com base em quatro critérios. O primeiro deles é a existência de Cecane ativo e de rede do Formação pela Escola, o que garante que há oferta de capacitação para os atores do PNAE que atuam no estado. O segundo diz respeito à proximidade de Minas Gerais da capital federal. Outros estados onde há Cecanes ativos são mais distantes de Brasília, o que dificultaria a logística de aplicação de entrevistas. Apesar de haver Cecane ativo no Distrito Federal, a análise do programa em Brasília não refletiria de forma fiel a situação de um programa nacional como o PNAE. O Distrito Federal tem características peculiares, inclusive de renda, que o destoam do restante do Brasil. Minas Gerais, por sua vez, tem grande quantidade de municípios distribuídos em vasto território, sofrendo influências de diversas regiões do país. A representatividade do estado é, portanto, o terceiro critério. O quarto é o fato de ter havido auditoria da CGU sobre o PNAE, em 2015, em municípios do estado, fato não ocorrido no Distrito Federal, por exemplo. As auditorias da CGU são relevantes ao FNDE, uma vez que auxiliam esta instituição no monitoramento e controle de seus programas.

A partir da definição da população, passou-se à análise dos relatórios. Foram analisados relatórios de auditoria da CGU, relatórios de oferta de capacitação do Cecane em Minas Gerais e relatório de oferta de cursos do PNAE e de Controle Social do Programa 
Formação pela Escola, todos do ano de 2015. A escolha do ano de 2015 como período de pesquisa se deu, tanto por conta do acesso a relatórios e documentos desse ano, quanto pela necessidade de se realizar entrevistas com atores que tenham sido capacitados recentemente. Apenas após a verificação desses relatórios, houve a seleção dos municípios onde foram realizadas as entrevistas.

Para se chegar à análise do relatório de fiscalizarão da CGU (Disponível em: < www.cgu.gov.br>. Acesso em 05 de dezembro de $2015^{4}$ ), foi preciso verificar a ocorrência de investigação sobre a aplicação dos recursos do PNAE. A controladoria realiza fiscalizações constantemente e a escolha dos programas e dos municípios investigados foi feita, em 2015, combinando informações do Censo, de matriz de vulnerabilidade e sorteio ${ }^{5}$. A lista de municípios mineiros investigados sobre o PNAE em Minas Gerias em 2015 foi comparada às listas daqueles onde foram ofertados cursos do Programa Formação pela Escola (Disponível em: 〈sistemas.fnde.gog.br/sife>. Acesso em 05 de janeiro de 2016) ${ }^{6}$ e daqueles cujos atores compareceram à capacitação do Cecane $\left(\right.$ UFOP, 2015) ${ }^{7}$. É importante esclarecer, no que tange à escolha da amostra, que na comparação entre os relatórios dos cursos do Formação pela Escola, de capacitação da Cecane e de auditoria da CGU, não houve coincidência de municípios em 2015, ou seja, os atores de nenhum município mineiro auditado em 2015 foram capacitados pelo Formação pela Escola ou pelo Cecane no mesmo ano. Sendo assim, optou-se por trabalhar em três municípios, o que justifica a estratégia de estudo de casos

\footnotetext{
${ }^{4}$ No site da CGU, procurou-se por Auditoria e Fiscalização, Programa de Fiscalização em Entes Federativos, Pesquisa de Relatórios. Buscou-se por relatórios na linha de atuação Avaliação da Execução de Programas de Governo / Relatório de Fiscalização em Municípios, ano 2015, estado de Minas Gerais.

${ }^{5}$ A partir de 2016, o PNAE passou a ser alvo de investigações constantes da controladoria para inibir o desvio de recursos (Disponível em www.cgu.gov.br. Acesso em 30 de outubro de 2016).

${ }^{6}$ Relatório solicitado ao FNDE por meio de contato com a equipe do programa Formação pela Escola pelos canais de comunicação disponibilizados no site da instituição.

${ }^{7}$ Relatório solicitado ao FNDE por meio de contato com a equipe do Programa Nacional de Alimentação Escolar pelos canais de comunicação disponibilizados no site da instituição.
} 
múltiplos. No primeiro município selecionado houve oferta do curso do PNAE pelo Formação pela Escola (não houve oferta do curso de Controle Social no estado em 2015). No segundo município selecionado, os atores do PNAE receberam capacitação pelo Cecane. O terceiro município foi auditado pela CGU. Dentre as opções, a escolha de Monte Carmelo (Formação pela Escola), Diamantina (Cecane) e Mateus Leme (CGU) se deu, portanto, pelo fato de os três apresentarem quantidade populacional (entre 30.000 e 48.100 habitantes) e riquezas (produto interno bruto entre 560 e 1.107 milhões de reais) aproximadas (Disponível em www.ibge.gov.br. Acesso em 29 de janeiro de 2016).

Quadro 5 - Municípios Selecionados: Número de Habitantes e PIB

\begin{tabular}{|c|c|c|}
\hline Município & População Estimada (2016) & $\begin{array}{c}\text { Produto Interno Bruto a Preços } \\
\text { Correntes em Mil Reais (2013) }\end{array}$ \\
\hline Diamantina & 48.095 & 563.264 \\
\hline Mateus Leme & 30.423 & 567.199 \\
\hline Monte Carmelo & 48.096 & 1.107 .663 \\
\hline
\end{tabular}

Fonte: elaborado pela autora com dados do IBGE.

Após a seleção dos municípios que seriam analisados, foi possível investigar de maneira mais aprofundada os relatórios de auditoria da CGU e de capacitação do Cecane. O relatório dos cursos do Programa Formação pela Escola apresentava somente a lista dos municípios onde houve capacitação sobre o PNAE e Controle Social em 2015, o que não demandou nenhuma investigação minuciosa.

Com a escolha da população e da amostra, restava selecionar as escolas onde seriam encontrados os profissionais, implementadores do PNAE, para a realização das entrevistas. Foi escolhida uma escola em cada um dos municípios definidos, de onde foram selecionados os entrevistados. A seleção das escolas partiu do relatório da CGU. Consta no relatório que aconteceram verificações locais de preparo e armazenamento da alimentação, mas não há especificação das escolas visitadas para que se chegasse a essa conclusão. Por meio dos 
canais de comunicação disponibilizados na página da CGU, foi feito contato com a área de auditoria da instituição, que encaminhou por e-mail a lista de escolas visitadas na fiscalização de 2015. A partir dessa lista e das informações fornecidas pelo Censo Escolar 2014 (Disponível em 〈www.dataescolabrasil.inep.gov.br >. Acesso em 10 de março de 2016), definiu-se que as unidades estudadas seriam três escolas urbanas de ensino fundamental, que tivessem um quantitativo parecido de alunos, entre 250 e 300 . Pesquisadora e entrevistados assinaram um termo de consentimento livre e esclarecido, que indica os objetivos da pesquisa e atende à solicitação de sigilo dos entrevistados. Por essa razão, não serão divulgados nem os nomes dos entrevistados, nem o das escolas selecionadas.

\subsection{Elaboração da Matriz de Análise}

A teoria para a aplicação do estudo de caso foi construída com base na investigação sobre implementação de políticas públicas e capacitações sobre o PNAE. A ideia da influência do implementador sobre a implementação, discutida inicialmente por Pressman e Wildavsky em 1968 (1984) e conceituada mais tarde por Lipsky (2010) e Linder e Peters (1987), foi testada para verificar se o fenômeno estudado pelos autores se repete no caso do PNAE, ainda que tenha havido capacitações sobre o programa.

Por se tratar da implementação de política pública consolidada, propõem-se três categorias temáticas de análise: a oferta de alimentos; as ações de educação alimentar e nutricional; e os cursos de capacitação oferecidos. Para Bardin (1977), as categorias reúnem grupos de elementos que possuem características comuns. A escolha das categorias foi feita com base na legislação do PNAE (BRASIL, 2009; 2013), que indica os fatores importantes para a implementação do programa. Observa-se que foram consideradas categorias de análise sobre as quais os implementadores entrevistados, os burocratas de nível de rua, têm influência direta. A escolha das categorias reflete o problema de pesquisa e responde de que maneira as 
capacitações influenciam a implementação e se conectam ao atendimento dos objetivos do PNAE.

A proposta metodológica inicial desta pesquisa permitiria que fossem feitas adequações às categorias de análise sugeridas, à medida que houvesse comprovação empírica dessa necessidade, por meio da grade mista para análise. Após a realização das entrevistas, constatou-se que não surgiram questões relevantes que justificassem a adequação ou inclusão de novas categorias de análise, mas apenas de códigos de análise de cada uma delas. O quadro seis representa de forma objetiva a matriz de análise da pesquisa, explicitando seu contexto de investigação, categorias e códigos. 
Quadro 6 - Matriz de Análise

\begin{tabular}{|c|c|c|c|}
\hline \multicolumn{4}{|c|}{ Matriz de Análise } \\
\hline \multicolumn{4}{|c|}{ Problema de Pesquisa } \\
\hline \multicolumn{4}{|c|}{$\begin{array}{l}\text { Como as capacitações dos atores envolvidos no Programa Nacional de Alimentação Escolar } \\
\text { influenciam a implementação do programa e se conectam aos objetivos pretendidos por ele em } \\
\text { municípios do estado de Minas Gerais. }\end{array}$} \\
\hline $\begin{array}{l}\text { Contexto de } \\
\text { Investigação }\end{array}$ & Fundamentação & Categorias de Análise & Códigos de Análise \\
\hline \multirow[t]{2}{*}{$\begin{array}{l}\text { Implementação do } \\
\text { PNAE }\end{array}$} & \multirow{2}{*}{$\begin{array}{c}\text { Bardach, 1979; } \\
\text { Lipsky, 2010; } \\
\text { Pressman, } \\
\text { Wildavsky, 1984; } \\
\text { Linder, Peters, 1987; } \\
\text { O’ Toole, 2000; Hill, } \\
\text { Hupe, 2002; Belik, } \\
\text { Chaim, 2009; } \\
\text { Chuproski et al 2012; } \\
\text { Sampaio et al 2013; } \\
\text { Gabriel et al 2014; } \\
\text { Cardoso et al 2015; } \\
\text { Kneipp et al, 2015. }\end{array}$} & $\begin{array}{l}\text { Educação Alimentar e } \\
\text { Nutricional (EAN) }\end{array}$ & $\begin{array}{l}\text { - Compreensão sobre o que } \\
\text { seja EAN; } \\
\text { - Promoção de ações de } \\
\text { EAN nas escolas; } \\
\text { - Cumprimento da } \\
\text { legislação; } \\
\text { - Interferência dos } \\
\text { implementadores; } \\
\text { - Interferência dos } \\
\text { familiares; } \\
\text { - Cumprimento dos } \\
\text { objetivos do PNAE quanto } \\
\text { à EAN. }\end{array}$ \\
\hline & & Oferta de Alimentos & $\begin{array}{l}\text { - Compreensão sobre a } \\
\text { oferta adequada; } \\
\text { - Interferência dos } \\
\text { implementadores; } \\
\text { - Cumprimento da legislação } \\
\text { para a compra de gêneros } \\
\text { alimentícios; } \\
\text { - Compra de gêneros da } \\
\text { agricultura familiar; } \\
\text { - Fiscalização da oferta pelo } \\
\text { CAE. }\end{array}$ \\
\hline $\begin{array}{c}\text { Capacitações sobre o } \\
\text { PNAE }\end{array}$ & $\begin{array}{l}\text { Leite et al, 2011; } \\
\text { Bandeira, 2012; } \\
\text { Santos et al, 2013; } \\
\text { Scarparo et al 2013; } \\
\text { Honório, Batista, } \\
\text { 2015. }\end{array}$ & $\begin{array}{c}\text { Capacitações sobre o } \\
\text { PNAE }\end{array}$ & $\begin{array}{l}\text { - Atores capacitados; } \\
\text { - Assuntos de interesse; } \\
\text { - Adequação dos cursos à } \\
\text { realidade municipal; } \\
\text { - Interferência dos } \\
\text { implementadores; } \\
\text { - Apoio de entes externos. }\end{array}$ \\
\hline
\end{tabular}

Fonte: elaborado pela autora. 


\subsection{Coleta de Dados}

Para a seleção dos entrevistados e realização das entrevistas, foi necessária a realização de coleta de dados preliminares por meio de pesquisa bibliográfica, fonte secundária de informações, e documental, fonte primária de informações.

A pesquisa bibliográfica se baseou em artigos científicos, teses, dissertações e livros que tratassem de implementação de políticas públicas e capacitações sobre o PNAE. A pesquisa documental se baseou em textos de legislação específica do programa ou de alguma forma relacionada a ele, relatórios de fiscalização e de capacitação. O relatório da CGU sobre o município de Mateus Leme apresenta o resultado de fiscalização de programas do Ministério da Educação, Ministério da Saúde e Ministério do Desenvolvimento Social e Combate à Fome. No caso da fiscalização do PNAE, não foram encontrados "indícios de impropriedades ou irregularidades dos documentos analisados relativos às licitações para aquisição dos gêneros alimentícios” (BRASIL, 2015). No que tange o relatório de capacitação do Cecane do ciclo 2014/2015, foram propostas "atividades que incluem a formação dos atores vinculados ao PNAE e a realização de assessoria técnica presencial aos municípios executores do programa" (UFOP, 2015). Foram realizadas, em novembro de 2014, as primeiras capacitações do ciclo nas cidades de Juiz de Fora e Governador Valadares, atendendo profissionais de 39 municípios. Foram abordadas questões sobre a atualização das legislações; segurança alimentar e nutricional e controle social; composição do cardápio; educação alimentar e nutricional e parâmetros curriculares nacionais; agricultura familiar; licitação e construção do termo de referência; panorama do PNAE e atribuições do CAE; acompanhamento e monitoramento da aquisição e do armazenamento dos gêneros alimentícios (UFOP, 2015). 
A análise de todo esse material direcionou a identificação dos atores responsáveis pela implementação do PNAE nos municípios bem como os pontos fundamentais de investigação sobre a implementação do PNAE e a oferta de capacitações sobre o tema.

A partir disso, foi construído o instrumento de coleta e realizada sua validação, com a aplicação de pré-teste em Brasília em maio de 2015. Foi selecionada uma escola cuja quantidade de alunos se assemelha àquela das escolas definidas em Minas Gerais. Foram realizadas duas entrevistas nessa escola, uma com a vice-diretora e uma com a merendeira. Além disso, foi feita entrevista com nutricionista vinculada à Secretaria de Educação do Distrito Federal. As três entrevistas contribuíram para o apontamento de lacunas no instrumento, que foi adequado seguindo essas referências.

A realização de entrevistas foi essencial para a pesquisa uma vez que a abordagem teórica utilizada é bottom-up, dos burocratas de nível de rua. O ponto de vista do implementador, portanto, é fundamental para o alcance dos objetivos específicos e resposder este problema de pesquisa. A lógica que relaciona os dados coletados às proposições feitas para a pesquisa está ligada à forma como as informações foram obtidas. No caso deste estudo, foram realizadas entrevistas semiestruturadas com os implementadores do programa nutricionistas, conselheiros, diretoras escolares, professoras, merendeiras ${ }^{8}-$ nos municípios escolhidos. Para identificar os entrevistados em cada município, foram coletados dados secundários acerca das capacitações, provenientes tanto do Cecane, quanto do curso do PNAE do Formação pela Escola, para verificar quem foram os agentes capacitados em 2015. Em alguns casos, o ator capacitado não estava disponível para conceder entrevista ficando a indicação do entrevistado por meio de escolha aleatória na escola pesquisada, no caso de professoras, diretoras e merendeiras, e por meio do Cadastro de Nutricionistas e Cadastro de

\footnotetext{
${ }^{8}$ As palavras diretora, professora e merendeira são usadas no feminino a partir deste ponto porque apeans mulheres ocupantes dessas posições foram entrevistadas nesta pesquisa.
} 
Conselheiros, disponíveis, respectivamente, no Sistema Integrado de Monitoramento, Execução e Controle (Simec) e no Sistema de Gestão de Conselhos (Sigecon), ambos ativos no FNDE.

Foram realizadas 11 entrevistas entre os meses de maio e junho de 2016, sendo que uma foi por e-mail, duas foram por telefone e oito foram realizadas pessoalmente. Com exceção da entrevista feita por e-mail, todas foram gravadas e somam um total de 204 minutos. O roteiro de entrevistas foi o mesmo para todos os atores entrevistados, o que contribuiu para a compreensão da implementação do programa sob diversos pontos de vista. Assim, foi feita a triangulação, explicada por Vergara (2005) como uma estratégia que utiliza diversos métodos para avaliar o mesmo fenômeno, tendo como finalidade determinar a posição de um objeto sob diversos pontos de vista. Para esta pesquisa foi realizada a triangulação de informantes, considerando que cada grupo de atores entrevistados nutricionistas, conselheiros, diretoras escolares, professoras e merendeiras - teve seu ponto de vista sob o mesmo tema.

As entrevistas realizadas foram suficientes para atingir o ponto de saturação, segundo Thiry-Cherques (2009). Para o autor, o ponto de saturação em pesquisa qualitativa é o momento em que a compreensão do fenômeno não será alterada pelo acréscimo de dados e informações. Segundo ele, esse momento se dá quando há "um mínimo de oito observações, correspondentes ao mínimo das 6 recomendadas, acrescidas das 2 necessárias à confirmação da saturação; e um máximo de 15 observações, correspondentes ao limite das 12 recomendadas, acrescidas de 1/3 de observações" (2009, p. 26). As respostas às questões propostas convergiram em vários aspectos, confirmando a teoria do autor. 
Quadro 7 - Entrevistados por Município

\begin{tabular}{|c|c|c|c|}
\hline Município & Cargo & Data da Entrevista & $\begin{array}{l}\text { Duração da } \\
\text { Entrevista }\end{array}$ \\
\hline \multirow{4}{*}{ Mateus Leme } & Diretora & \multirow{3}{*}{$31 / 05 / 2016$} & $00: 16: 00$ \\
\hline & Professora & & 00:08:55 \\
\hline & Merendeira & & $00: 13: 10$ \\
\hline & Nutricionista & $\begin{array}{c}\text { E-mail enviado em } \\
31 / 05 / 2016\end{array}$ & E-mail \\
\hline \multirow{5}{*}{ Diamantina } & Diretora & \multirow{5}{*}{$14 / 06 / 2016$} & $00: 24: 20$ \\
\hline & Professora & & $00: 10: 21$ \\
\hline & Merendeira & & 00:09:02 \\
\hline & Nutricionista & & 01:22:00 \\
\hline & Conselheiro & & $00: 13: 19$ \\
\hline \multirow{2}{*}{ Monte Carmelo } & Diretora & $16 / 06 / 2016$ & $00: 14: 22$ \\
\hline & Nutricionista & $17 / 06 / 2016$ & 00:14:06 \\
\hline
\end{tabular}

Fonte: elaborado pela autora.

\subsection{Análise de Dados}

Para a análise de dados da pesquisa, adotou-se a metodologia de análise de conteúdo. Segundo Bardin (1977, p. 38), "análise de conteúdo é um conjunto de técnicas de análise das comunicações que utiliza procedimentos sistemáticos e objetivos de descrição do conteúdo das mensagens". Sendo assim, supõe-se que, fazendo uso correto das técnicas, seja possível analisar o que é dito e o que não é explicitado em uma entrevista, o que torna o método rico e interessante. Para Trivinos (1987, p. 162) "não é possível que o pesquisador detenha sua atenção exclusivamente no conteúdo manifesto dos documentos. Ele deve aprofundar sua análise tratando de desvendar o conteúdo latente que eles possuem". 
A análise teve início após o período de realização das entrevistas. Inicialmente foram feitas as transcrições, fase em que todas as entrevistas foram transformadas em texto. Esse processo foi feito sem o uso de software de apoio. Para os registros, os conteúdos foram tratados de forma transversal, ou seja, tudo o que o entrevistado falou a respeito de cada tema abordado na entrevista, foi transcrito e agrupado para a análise. O processo seguiu após a definição dos códigos de análise e elaboração de matriz para registro das ocorrências, que foram divididas em categorias. Nessa matriz foram registradas as falas que justificavam cada um dos códigos estabelecidos, procedendo-se à análise dos conteúdos explícitos. Posteriormente, os códigos e os textos das entrevistas foram relidos e aprofundados, levandose em conta o que se encontrou na literatura a respeito de cada categoria analisada. $\mathrm{O}$ preenchimento da matriz de análise, respeitando as categorias e códigos definidos, foi a forma sistematizada e objetiva encontrada para se fazer a análise de conteúdo. A conclusão dessa etapa foi a base para o desenvolvimento do relatório de análise, cujo objetivo foi relacionar os resultados encontrados com a teoria estudada.

Este capítulo expôs a metodologia utilizada para o alcance das respostas ao problema de pesquisa proposto. A seguir, serão apresentados e discutidos os resultados encontrados na fase de coleta de dados. 


\section{RESULTADOS E DISCUSSÃO}

Este capítulo apresenta os resultados e discussões acerca das categorias de análise explicitadas na metodologia da pesquisa e tem como foco responder aos seus objetivos específicos: descrever como ocorre a implementação do PNAE nos municípios mineiros; analisar como a capacitação de nutricionistas, conselheiros, merendeiras, professores e diretores escolares influencia a implementação do programa; investigar o alcance dos objetivos do programa nos municípios selecionados.

Os objetivos específicos da pesquisa foram construídos para a compreensão de um fenômeno contemporâneo - a influência das capacitações na implementação de uma política pública brasileira, investigado por meio de estudo de casos múltiplos, em três municípios do estado de Minas Gerais. O objeto de pesquisa deste trabalho, o PNAE, é um dos programas mais antigos e relevantes da educação brasileira. Por ser nacional, o programa alcança a todos os estados e municípios do país, onde pode ser implementado de formas distintas, seja por questões relativas ao implementador, seja pelo surgimento de diferentes problemas, inerentes

à fase de implementação (LIPSKY, 2010; PRESSMAN, WILDAVSKY, 1984). Com a intenção de se alcançar os objetivos do programa, alinhando informações pertinentes para tornar a implementação mais efetiva, são ofertados cursos de capacitação pelo FNDE - por meio do programa Formação pela Escola e pelos Cecanes. Essas capacitações são voltadas para os atores envolvidos na implementação, são amplamente recomendadas pelos órgãos de controle e atendem à missão estratégica do FNDE de prestar assistência técnica sobre os programas da instituição. Sendo assim, o PNAE é o objeto de uma investigação acerca da implementação de uma política pública de educação, levando-se em conta as capacitações oferecidas a seu respeito. Questiona-se aqui se há de fato alguma relação entre as estratégias 
adotadas para a capacitação dos atores implementadores do PNAE e o alcance dos objetivos do programa.

A apresentação e discussão dos resultados encontrados foi dividida em três seções. $\mathrm{Na}$ primeira, será apresentada a categoria de análise Educação Alimentar e Nutricional, que tem a finalidade de demonstrar a percepção dos entrevistados sobre um dos temas mais importantes para o PNAE. A segunda seção trata da categoria de análise Oferta de Alimentos, em que serão apresentados os resultados referentes à percepção dos entrevistados em relação ao tema. A terceira e última seção deste capítulo se ocupa em discutir as Capacitações sobre o PNAE oferecidas aos atores do programa, terceira categoria de análise desta pesquisa. Esta seção apresenta ainda uma proposta de escala que poderá ser usada em pesquisas futuras para investigar a efetividade das capacitações para a implementação do programa em estados e municípios. Ao final de cada seção, foi construído um quadro que resume os principais resultados encontrados e sua relação com os objetivos específicos propostos.

\subsection{Educação Alimentar e Nutricional}

A inclusão da educação alimentar e nutricional no processo de ensino e aprendizagem é uma das diretrizes do PNAE que deve ser promovida por estados, Distrito Federal e municípios (BRASIL, 2009). Sendo assim, a primeira categoria de análise se ocupa em investigar de que maneira essa diretriz é compreendida pelos entrevistados e implementada nos municípios.

Segundo a Lei 11.947 (BRASIL, 2009), os temas da alimentação e nutrição, bem como o desenvolvimento de práticas saudáveis de vida, devem ser abordados nas escolas na perspectiva da segurança alimentar e nutricional. A Resolução 26 (BRASIL, 2013) apresenta uma definição do que pode ser considerado educação alimentar e nutricional. É expresso na legislação que se trata de ações formativas, tanto para os alunos quanto para os profissionais 
envolvidos com o programa, no sentido de estimular a adoção de práticas alimentares saudáveis, seja pela oferta de alimentos, seja pela utilização dos hábitos alimentares como instrumento pedagógico, dentre outras ações. A partir da definição expressa na legislação fez-se necessário examinar como o assunto é compreendido pelos atores envolvidos no programa. A expectativa era de que todos os entrevistados, que têm papéis claros e relevantes na implementação do programa, conseguissem apresentar suas percepções em consonância com o que está definido nas legislações estudadas, além de terem conhecimento sobre as ações desenvolvidas na escola para a promoção da educação alimentar e nutricional.

O resultado sugere que, de modo geral, entre os entrevistados há pontos de convergência sobre o que seja a educação alimentar e nutricional. As ideias de alimentação saudável, variada e balanceada, assim como a influência que se pode exercer sobre as crianças para a construção de hábitos alimentares saudáveis, são apontadas como centrais na discussão acerca da educação alimentar e nutricional. Para promover essas ideias entre os alunos, além do próprio fornecimento de alimentos saudáveis, as escolas pesquisadas utilizam outras estratégias. A abordagem principal sobre os alimentos e a alimentação de qualidade está envolvida no conteúdo das disciplinas, ainda que de forma pontual e pouco aprofundada. A ação com os alunos é feita, basicamente, em sala de aula, pelos próprios professores, mas há algumas campanhas temáticas nas escolas contra o consumo de alimentos industrializados como salgadinhos, biscoitos recheados, refrigerantes. Essas campanhas são motivadas principalmente pelos lanches pouco saudáveis que os alunos trazem de casa, a despeito de haver a merenda oferecida pela escola. Os lanches trazidos de casa suscitam uma discussão sobre a contribuição dos pais na formação dos hábitos alimentares das crianças.

Os padrões alimentares das famílias não haviam sido considerados inicialmente para esta pesquisa. Entretanto, a associação da educação alimentar e nutricional com os hábitos que os alunos têm em casa foi apontada por vários entrevistados, o que fez necessária sua 
análise e discussão. Dos 11 entrevistados, seis sugerem que a educação alimentar e nutricional envolva as famílias, o que acontece de forma modesta nas reuniões de pais no início do ano. Os relatos apontam que nessas reuniões são tratados assuntos sobre a boa alimentação, fazendo-se alusão à oferta de uma alimentação balanceada e saudável pela escola. É notável, contudo, que o trabalho realizado nas escolas encontra a barreira dos hábitos alimentares das famílias. As crianças que não comem a merenda da escola, e preferem trazer o próprio lanche de casa, normalmente levam lanches pouco saudáveis, baseados principalmente em alimentos industrializados. Em alguns casos, segundo os entrevistados, a alegação dos pais é diretamente relacionada às preferências, tolerância e seletividade das crianças em relação aos alimentos. As evidências da influência familiar na alimentação das crianças estão alinhadas com a literatura estudada, ficando comprovada sua exacerbação para o ambiente escolar por meio desta pesquisa (KNEIPP C. et al, 2015; CARDOSO et al, 2015; SAMPAIO et al, 2013; CHUPROSKI et al, 2012). Maior aprofundamento sobre o assunto poderá ser tratado em pesquisa futura.

Porque, por exemplo, o menino vai deixar de trazer o biscoito recheado só quando o pai não comprar, quando o pai mandar uma fruta em vez de mandar o biscoito recheado. Na nossa escola nós já servimos alimentação balanceada, mas infelizmente, se a família não nos ajudar, nós não vamos vencer a obesidade. (ENTREVISTADO 1, 2016)

A gente começou até a fazer um trabalho com os pais para diminuir esse tipo de lanche, Cheetos, suco de caixinha, e considerar o nosso, valorizar mais o nosso lanche, porque é bem mais saudável. E a gente fala muito em reuniões, não só no início do ano, que a gente propõe essa mudança de lanche, e usar mais o lanche da escola, mas no dia a dia aqui da escola, a gente tendo a oportunidade, precisando, a gente sempre fala dessa questão do lanche saudável. Então a gente envolve, não diretamente, os pais, até porque eles trabalham. São pessoas com um nível socioeconômico que precisam realmente trabalhar praticamente o dia inteiro fora, então não têm esse tempo livre disponível para vir aqui na escola com muita frequência, então a gente fala no início do ano, nas reuniões bimestrais, se precisar a gente reforça. (ENTREVISTADO 5, 2016)

A preocupação é da escola, não da família. A gente está dando alimentação saudável. A escola, com certeza, está muito empenhada nisso. Toda reunião de pais a gente fala da alimentação, que a alimentação da escola é boa, é nutritiva, a gente passa cardápio pra eles. Porque tem o cardápio. A escola tem o cardápio que o nutricionista da secretaria passa. (ENTREVISTADO 6, 2016) 
Os pais, mesmo que você oriente, que você fale que tem alimentação na escola, de repente o pai ainda manda o lanche para a criança. Então, tem que ver o que é que manda pra essa criança. Aí, aquele que leva o biscoito recheado leva não só pra ele, mas divide com os colegas, então o hábito continua errado do mesmo jeito. (ENTREVISTADO 8, 2016)

A questão da quantidade de alimento consumido pelos alunos também tem sido foco de enfrentamento nas escolas. A abordagem sobre o consumo exagerado de alimento tem sido uma preocupação nas escolas tanto por seu viés educativo, quanto em razão de saúde, relacionada à obesidade infantil. Essa abordagem está alinhada com a legislação do programa, que é expressa quanto à necessidade de utilização da alimentação escolar para combater problemas de saúde que possam estar relacionados a hábitos pouco saudáveis (BRASIL, 2006). É notável que a campanha para que não haja oferta excessiva de alimentos é feita não apenas com os alunos, mas também e principalmente com as merendeiras. São elas as profissionais responsáveis por servir os alunos e costumam ser mais permissivas com o que e quanto a criança pode comer. Essa situação está alinhada à perspectiva bottom-up, característica importante da implementação do PNAE, reforçando a influência dos implementadores diretos no resultado da política e confirmando a teoria dos burocratas de nível de rua (LIPSKY, 2010).

Temos que colocar a quantidade ideal no prato para não haver repetição, porque se a gente deixar tem menino que quer repetir quatro, cinco vezes. Isso não é fome. Acostuma a comer muito! Então a gente precisa também educar nesse ponto. Nós estamos na campanha mesmo, até com as serventes ${ }^{9}$, porque elas acham que os meninos têm que comer o tanto que eles quiserem, e às vezes não é por aí. Se eu deixo o menino repetir duas, três vezes, então ele pode comer biscoito recheado... Porque aí, a escola não está contribuindo. (ENTREVISTADO 1, 2016)

Porque a nutricionista quer assim, o que tiver hoje de merenda, os alunos têm que comer, mas eles não comem. Se eu forçar, vai ter muito desperdício. Então, quer só arroz, eu dou só arroz. É melhor do que ficar de estômago vazio. (ENTREVISTADO 3, 2016).

\footnotetext{
${ }^{9}$ Em alguns municípios as merendeiras também são denominadas serventes.
} 
Eu acho até mesmo que há uma relação muito grande da alimentação, limite e, automaticamente, aprendizagem. Vejo também, às vezes, criança que repete mais de uma ou duas vezes, mas querem só o arroz e a carne. Às vezes, nem o feijão pode ter. E não aceita verdura. Então, para mim, isso não é uma alimentação saudável. Eu considero que é aquilo que você come, mas você come um tanto, uma porção de cada coisa que o seu organismo precisa para funcionar saudavelmente, sem exageros. (ENTREVISTADO 5, 2016)

Outro ponto de destaque é a associação imediata entre a figura do nutricionista, montagem dos cardápios e educação alimentar e nutricional. $\mathrm{O}$ fato de haver um profissional responsável pela elaboração dos cardápios é fundamental para a compreensão dos entrevistados sobre o que é educação alimentar e nutricional. O nutricionista é visto pelos entrevistados de modo geral como indispensável para garantir o equilíbrio e qualidade da alimentação nas escolas. Contudo, apesar de sua importância no processo de implementação do PNAE, a Lei 11.947 (BRASIL, 2009) é expressa quanto ao compartilhamento da competência entre profissionais de educação e profissionais de nutrição para promoção da educação alimentar e nutricional. Apesar dos esforços notáveis nas escolas, as falas de alguns entrevistados apontam certa dificuldade em se realizar essa diretriz, seja pela sobrecarga de responsabilidades atribuídas aos nutricionistas, seja pelo engajamento heterogêneo dos outros atores no processo. Por exemplo, não há muito contato entre nutricionistas e professores, o que pode causar uma ruptura na transmissão de informações para o aluno. Além disso, nem sempre o que os nutricionistas preconizam pode ser fielmente seguido por educadores e merendeiras, já que as instruções formais encontram obstáculos no dia a dia, que pede adequações. Essas questões ratificam as discussões encontradas na literatura por sua clara demonstração da interferência do implementador na política e a dificuldade de convergência de seus interesses com os objetivos da própria política (LIPSKY, 2010; BARDACH, 1979; PRESSMAN, WILDAVSKY, 1984; LINDER, PETERS, 1987).

A nutricionista quer que a gente faça salada e que a gente coloque na mesa para as crianças mesmas se servirem. Não dá certo. É igual a gente conversa com ela nos cursos. Cada escola é uma realidade. (ENTREVISTADO 3, 2016) 
Nós temos uma nutricionista que acompanha todas as escolas da rede municipal. É ela que toma conta dessa parte da alimentação das escolas. (ENTREVISTADO 10, 2016)

Eu acho que seria interessante um trabalho interdisciplinar com o professor, para que essa informação chegue até as escolas. Isso é o que eu acho que falta na parte de educação alimentar e nutricional no município: divulgar através do professor, para que a informação chegue para o aluno. Agora, não pode ficar preso também só ao que o FNDE coloca no livro. Acho que tem que ser mais amplo, porque de repente o que o FNDE coloca no livro é generalizado, é pra todo o Brasil, e cada escola, cada município tem a sua situação. (ENTREVISTADO 8, 2016)

Apresenta-se a seguir quadro com o resumo dos resultados desta categoria de análise, relacionando-os aos objetivos pertinentes, almejados na pesquisa. 
Quadro 8 - Relação da Primeira Categoria com os Objetivos Específicos Relacionados

\begin{tabular}{|c|c|c|}
\hline \multicolumn{3}{|c|}{$1^{\circ}$ Categoria de Análise - Educação Alimentar e Nutricional (EAN) } \\
\hline $\begin{array}{c}\text { Objetivos } \\
\text { Específicos } \\
\text { Relacionados }\end{array}$ & $\begin{array}{l}\text { Descrever como ocorre a } \\
\text { implementação do PNAE nos } \\
\text { municípios mineiros }\end{array}$ & $\begin{array}{l}\text { Comparar o alcance dos objetivos do } \\
\text { programa nos municípios selecionados }\end{array}$ \\
\hline \multirow{6}{*}{ 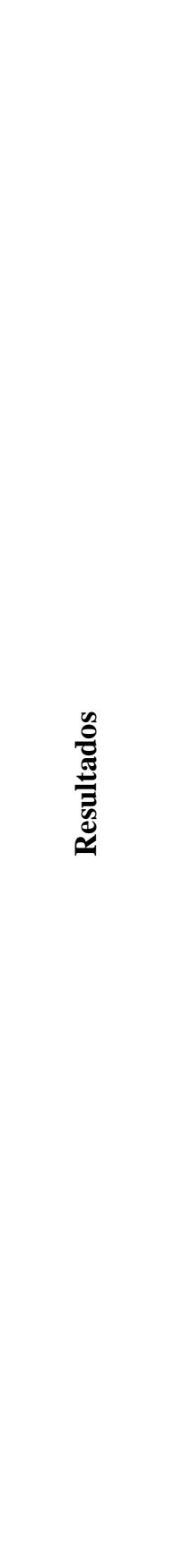 } & $\begin{array}{l}\text { EAN é implementada de acordo } \\
\text { com a legislação, mas } \begin{array}{r}\text { sofre } \\
\text { interferências }\end{array} \\
\text { implementadores. }\end{array}$ & $\begin{array}{l}\text { Sentido de educação alimentar e } \\
\text { nutricional é compreendido de forma } \\
\text { homogênea e relacionado à } \\
\text { alimentação saudável, variada e } \\
\text { balanceada. }\end{array}$ \\
\hline & $\begin{array}{l}\text { EAN é tratada como conteúdo } \\
\text { das disciplinas dadas em sala de } \\
\text { aula e em campanhas temáticas. }\end{array}$ & $\begin{array}{l}\text { Objetivo de promover a alimentação } \\
\text { saudável nas escolas é alcançado por } \\
\text { meio da oferta de alimentos, } \\
\text { promoção de campanhas temáticas e } \\
\text { inclusão do assunto no currículo } \\
\text { escolar. }\end{array}$ \\
\hline & $\begin{array}{l}\text { Interferência das diretoras nas } \\
\text { questões da alimentação se } \\
\text { mostrou fundamental para } \\
\text { expandir o raio de discussão do } \\
\text { tema, da sala de aula para a } \\
\text { escola e para as famílias. }\end{array}$ & \multirow{3}{*}{$\begin{array}{l}\text { À luz da EAN, o cumprimento dos } \\
\text { objetivos do programa foi percebido } \\
\text { como homogêneo em todos os } \\
\text { municípios pesquisados. }\end{array}$} \\
\hline & $\begin{array}{l}\text { Quantidade de alimentos servida } \\
\text { aos alunos sofre interferência } \\
\text { relevante do implementador. }\end{array}$ & \\
\hline & $\begin{array}{l}\text { Nutricionista é visto como } \\
\text { principal responsável } \\
\text { programa. }\end{array}$ & \\
\hline & \begin{tabular}{lccr} 
Influência & dos & pais & na \\
alimentação & & \multicolumn{2}{c}{ interfere } \\
diretamente & no & sucesso & da \\
implementação. & &
\end{tabular} & $\begin{array}{l}\text { Dificuldades para o cumprimento do } \\
\text { objetivo se dão por conta de } \\
\text { sobrecarga de responsabilidades } \\
\text { atribuídas aos nutricionistas e pelo } \\
\text { engajamento heterogêneo dos outros } \\
\text { atores na implementação da EAN nas } \\
\text { escolas. }\end{array}$ \\
\hline
\end{tabular}

Fonte: elaborado pela autora. 


\subsection{Oferta de Alimentos}

A oferta de alimentos é central para o PNAE, cuja implementação está invariavelmente relacionada aos itens componentes da merenda escolar. De acordo com o artigo segundo da Lei $\mathrm{n}^{\circ} 11.947$ (BRASIL, 2009), o emprego da alimentação saudável e adequada é uma das diretrizes do programa. Para fins dessa legislação, pode-se entender por alimentação adequada aquela que utiliza alimentos variados, que respeitam a cultura e as tradições locais, além dos hábitos alimentares saudáveis. Entretanto, essa descrição não é exaustiva, razão pela qual, para se compreender a implementação do programa, investigou-se, como segunda categoria de análise, a percepção dos entrevistados em relação à oferta de alimentos, questionando sua adequação aos moldes do PNAE. Com base na legislação do programa, esperava-se que, para seu cumprimento, os entrevistados apontassem a adequação da oferta de alimentos com as diretrizes do PNAE.

Os resultados mostraram que a avaliação geral dos entrevistados acerca da oferta de alimentos é claramente positiva. Houve predominância do entendimento de que a oferta variada, balanceada e baseada em alimentos naturais atende aos critérios de adequação do programa. Além disso, para os entrevistados, faz parte dos critérios de adequação da oferta o fato de ela ser baseada em um cardápio, que é elaborado pelo nutricionista em consonância com as entregas da agricultura familiar. A agricultura familiar foi um dos pontos mais citados pelos entrevistados na discussão sobre a oferta adequada. Esse tipo de modelo produtivo é claramente bastante comum no âmbito do PNAE porque as compras feitas com a agricultura familiar visam respeitar à exigência legal de utilização de no mínimo $30 \%$ dos recursos repassados pelo FNDE com a aquisição de alimentos provenientes diretamente desses produtores rurais (BRASIL, 2006). Para além das diretrizes legais, os entrevistados abordaram a agricultura familiar para pontuar a qualidade dos produtos oferecidos, para citar a possibilidade de ofertar gêneros típicos da região, mantendo a cultura alimentar local, e para 
justificar a frequência com que os alimentos são entregues, garantindo que as escolas estejam sempre abastecidas.

Tem uma merenda bacana, sabe? Tem carne, legumes, frutas... A gente recebe tudo. Você pode ir lá na despensa agora que tem de tudo. Toda semana a gente recebe da agricultura familiar e são boas as coisas que eles mandam. (ENTREVISTADO 1, 2016)

Toda semana chega a agricultura familiar. Eles trazem o que eles têm no momento. Eles têm que suprir todas as escolas, então, a partir do que eles têm é que se elabora o cardápio. Então, o cardápio é variado. (ENTREVISTADO 3, 2016)

Quanto à merenda escolar aqui no município eu acho muito boa, comparado com outros municípios aqui de perto que a gente sabe da realidade. Aqui a gente tem o pessoal da agricultura familiar, que tem que entregar $30 \%$ do que é licitado da merenda. Tem uma variedade enorme de folhas em geral e vem tudo da agricultura e a maior parte é orgânico. (ENTREVISTADO 11, 2016)

A questão do abastecimento foi a que se mostrou mais desafiadora para a manutenção da oferta de alimentos. O estado de Minas Gerias é grande em extensão e em número de municípios, 853, e muitos deles agregam territorial e administrativamente pequenos distritos. Apesar de não ter havido menção significativa pelos entrevistados de dificuldades de abastecimento nos municípios estudados, em razão das compras feitas da agricultura familiar, o abastecimento de escolas em distritos e em áreas rurais é uma questão que gera alguns contratempos. A distância de alguns distritos dos municípios sede acarretam complicações quanto à logística na entrega. Já o tamanho diminuto das escolas nessas localidades gera o problema da falta de interesse do produtor rural em abastecer uma escola que tem pouca demanda. Quando não há fornecimento pela agricultura familiar, as prefeituras podem esbarrar em muita burocracia para realizar as compras. A aquisição de gêneros da agricultura familiar pode ser realizada por meio de licitação comum, pregão ou chamada pública, esta com dispensa do procedimento licitatório. Quando a compra por chamada pública não é possível, o processo licitatório para compra por pregão é recomendável (BRASIL, 2002; 2006; 2009). 
Várias escolas e creches de distritos já recebem da agricultura familiar. Isso pra gente é um alívio em termos de logística. É muito burocrático fazer uma compra pública, amarra muito a alimentação escolar. O registro de preços facilita nesse sentido de acesso ao alimento e a chamada pública facilita a entrega direta no município, direto na escola. Isso favoreceu um cardápio mais variado. [...] Então, onde tem agricultura familiar a gente não precisa se preocupar, porque a agricultura entrega de 15 em 15 dias. Algumas escolas recebem de 15 em 15 dias da agricultura, mas outras escolas não. Dependem da compra e da entrega feitas pelo município. (ENTREVISTADO 8, 2016)

Tem os problemas de safra, e agora com a inflação está esse negócio de um mês é um preço, um mês é outro. A gente não consegue acompanhar, porque a licitação da merenda é anual, então muda muito o valor, e isso é difícil. (ENTREVISTADO 11, 2016)

Apesar da hegemonia de respostas favoráveis à adequação da oferta de alimentos nas escolas, há alguns registros destoantes, mas significativos, que apontam para uma merenda de baixa qualidade. Nesses casos, normalmente, há uma associação entre a merenda servida na escola e a alimentação que a criança recebe fora da escola. Foram citados alguns casos de vulnerabilidade, em que a refeição mais importante da criança é aquela feita na escola. Isso reforça a relevância do PNAE como programa social e humanitário, além de seu papel educacional.

[...] Toda segunda e toda sexta é uma alimentação mais forte, né, mais reforçada. Porque a gente entende que na segunda-feira o aluno já vem de um final de semana que provavelmente ele comeu pouco, então, na segunda-feira a gente faz uma alimentação mais reforçada pra ele comer. $\mathrm{Na}$ sexta, a gente entende também que ele vai comer pouco no fim de semana. Então, na segunda e na sexta são dias que o lanche é mais reforçado. (ENTREVISTADO 10, 2016)

Tem menino que a alimentação não é só a alimentação aqui na escola, mas, por exemplo, pode ser que seja só na refeição da escola que eles vão comer carne, que vai ter um legume, porque, dentro de casa, é só arroz e feijão. (ENTREVISTADO 1, 2016)

Outro ponto de alerta percebido pelos entrevistados foi em relação às recomendações nutricionais per capita preconizadas pelo FNDE (BRASIL, 2013). Algumas entrevistas apontam para preparos que podem exceder ou faltar, não correspondendo às reais necessidades das escolas. Por conta disso, para que não haja desperdício ou para que a oferta de alimentos seja suficiente para os alunos, os entrevistados apontam para a necessidade de se valorizar a experiência das merendeiras, ainda que haja uma ficha técnica orientadora para a 
preparação dos alimentos e suas quantidades. Essa situação é reforçadora da teoria dos

burocratas de nível de rua, uma vez que mostra de forma clara e contundente a imprescindível

adequação que a política sofre quando de sua implementação (LIPSKY, 2010; BARDACH,

1979; PRESSMAN, WILDAVSKY, 1984; LINDER, PETERS, 1987).

Por mais que tenha uma ficha técnica, a servente segue muito a prática dela, a correria do dia a dia. É importante você respeitar a prática da servente porque ela já tem a mão adequada, ela já sabe quem é que repete na escola, quem é que não repete, ela já sabe quanto que coloca no prato de cada criança, principalmente em escola pequena, então é bom você respeitar esse hábito. Os per capitas de acordo com o que o FNDE preconiza ficam excedentes. A merenda fica... A quantidade produzida é muita! Então, tem que reduzir os per capitas pra que a oferta seja adequada. [...]. Se você está reduzindo per capita, você vai reduzir oferta, por exemplo, você vai reduzir caloria, você vai reduzir ferro e eu não estou atendendo à lei. Não adianta você tentar atender à lei e ficar com aquela oferta excessiva, oferta excedente. Vai gerar é desperdício isso. [...] De repente, aumentar o número de refeições, fracionar mais o número pra atender o aporte calórico, o aporte proteico, enfim, vitaminas e minerais de um modo geral, mas respeitar a experiência da servente, aquela quantidade que ela faz, porque ela sabe o que vai fazer, não vai faltar pra ninguém, mas também não vai virar desperdício. (ENTREVISTADO 8, 2016)

É tudo com medida, medido tudo certinho. [Nutricionista] fala quanto que é pro menino, quantos gramas a gente deve fazer e ai você multiplica aqui pra você fazer. Agora de manhã são 250 pessoas no mínimo, pra mim [sic] fazer o lanche pra eles todos. Então, o que eles [nutricionistas] falam lá na teoria é pouco, então a gente tem que se desdobrar pra dar pra todo mundo. [...]É muita gente, e é a gente que sabe a quantidade. (ENTREVISTADO 7, 2016)

O quadro a seguir apresenta, de forma resumida, a relação entre os resultados desta categoria de análise e os objetivos da pesquisa pertinentes a ela. 
Quadro 9 - Relação da Segunda Categoria com os Objetivos Específicos Relacionados

\begin{tabular}{|c|c|c|}
\hline \multicolumn{3}{|c|}{$2^{\circ}$ Categoria de Análise - Oferta de Alimentos } \\
\hline $\begin{array}{c}\text { Objetivos } \\
\text { Específicos } \\
\text { Relacionados }\end{array}$ & $\begin{array}{l}\text { Descrever como ocorre a implementação do } \\
\text { PNAE nos municípios mineiros }\end{array}$ & $\begin{array}{l}\text { Comparar o alcance dos objetivos do } \\
\text { programa } \\
\text { selecionados }\end{array}$ \\
\hline \multirow{4}{*}{ 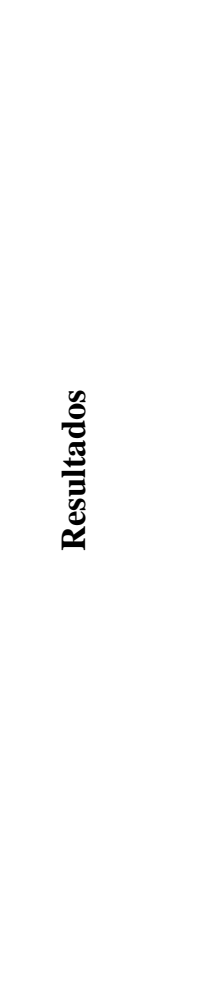 } & $\begin{array}{l}\text { Em relação à implementação, a oferta } \\
\text { acontece de acordo com a legislação } \\
\text { pertinente, sofrendo interferências dos } \\
\text { implementadores. A valorização da } \\
\text { experiência das merendeiras, por exemplo, } \\
\text { influencia diretamente a implementação. }\end{array}$ & $\begin{array}{l}\text { O entendimento sobre oferta de } \\
\text { alimentos é homogêneo e positivo, } \\
\text { relacionando-se a uma oferta } \\
\text { variada, balanceada e baseada em } \\
\text { alimentos naturais, atendendo aos } \\
\text { critérios de adequação do PNAE. }\end{array}$ \\
\hline & $\begin{array}{l}\text { Compra de gêneros alimentícios é feita por } \\
\text { licitação comum, pregão ou chamada } \\
\text { pública. }\end{array}$ & \multirow{2}{*}{$\begin{array}{l}\text { A compra de gêneros } \mathrm{da} \\
\text { agricultura familiar cumpre os } \\
\text { requisitos legais. }\end{array}$} \\
\hline & $\begin{array}{l}\text { Agricultura familiar é citada pela } \\
\text { qualidade dos produtos oferecidos, pela } \\
\text { possibilidade de oferta de gêneros típicos } \\
\text { da região e pela frequência com que os } \\
\text { alimentos são entregues. }\end{array}$ & \\
\hline & $\begin{array}{l}\text { Abastecimento: questão desafiadora para a } \\
\text { manutenção da oferta de alimentos. }\end{array}$ & $\begin{array}{l}\text { CAE fiscaliza a oferta e } \\
\text { distribuição de alimentos. }\end{array}$ \\
\hline
\end{tabular}

Fonte: elaborado pela autora. 


\subsection{Capacitações sobre o PNAE}

A necessidade de realização de capacitações sobre o PNAE é claramente citada tanto em sua legislação específica, quanto na missão do FNDE (BRASIL, 2009; 2013). Atribui-se à autarquia a competência de colaborar com estados e municípios no processo de capacitação dos atores envolvidos na implementação do programa a fim de favorecer sua operacionalização. O curso do PNAE oferecido pelo programa Formação pela Escola e as capacitações realizadas pelo Cecane mineiro são exemplos de como a União tem cumprido as exigências. Sendo assim, como terceira categoria de análise, investigou-se a percepção dos entrevistados quanto a essas capacitações, como são realizadas e de que maneira influenciam a implementação do PNAE. Com base tanto na legislação do programa quanto na literatura referente às capacitações sobre PNAE, a expectativa da investigação era de que os atores apontassem seus pontos positivos e negativos.

Os resultados mostraram que as capacitações sobre o programa são voltadas principalmente para nutricionistas e merendeiras. Ficou claro que as capacitações dos nutricionistas são, normalmente, realizadas nacionalmente pelo FNDE ou regionalmente pelo Cecane. Esses profissionais, por sua vez, são os responsáveis por capacitar as merendeiras nos municípios. Professores, diretores e conselheiros entrevistados não tinham conhecimento sobre oferta de capacitações referentes ao PNAE. As exceções foram uma diretora, que havia sido capacitada pelo nutricionista do município, e uma professora. Em comum entre as duas entrevistadas, existe o fato de que as prefeituras de seus municípios mantêm parcerias com entidade rural ligada ao "sistema S"10, no primeiro caso, e Faculdade de Nutrição de uma

\footnotetext{
${ }^{10}$ Termo que define o conjunto de organizações das entidades corporativas voltadas para o treinamento profissional, assistência social, consultoria, pesquisa e assistência técnica, que além de terem seu nome iniciado com a letra S, têm raízes comuns e características organizacionais similares. Fazem parte do sistema S: Serviço Nacional de Aprendizagem Industrial (Senai); Serviço Social do Comércio (Sesc); Serviço Social da Indústria (Sesi); e Serviço Nacional de Aprendizagem do Comércio (Senac). Existem ainda os seguintes: Serviço Nacional de Aprendizagem Rural (Senar); Serviço Nacional de Aprendizagem do Cooperativismo (Sescoop); e Serviço
} 
Universidade Federal, no segundo caso. Os acordos feitos entre essas entidades e as prefeituras parecem benéficos à capacidade de oferta de capacitações para a melhoria da capacidade técnica dos atores do programa. A situação dos atores capacitados, com foco em nutricionistas e merendeiras, confirma o que foi encontrado na literatura (BELIK, CHAIM, 2009).

Eu estou há dois anos na diretoria desta escola e nunca fui capacitada. Agora, teve para o pessoal da cantina. [...] Ano passado teve, este ano também já teve. Agora, pra mim, como gestora, não. (ENTREVISTADO 1, 2016)

Eu já fui chamada pela secretaria municipal de educação, juntamente com outros diretores, para nós recebermos orientações sobre a conscientização do uso adequado dos alimentos, porque costumava ter alimentos vencidos, ou por vencer, em estoque na escola. Então, eu já recebi esse tipo de orientação, sobre questão de conscientização, sobre como mexer no inventário, sobre quando entregar esse inventário pronto... Agora, cursos, depois que eu estou aqui, as cantineiras já passaram por dois cursos em período de férias. Então, elas recebem. (ENTREVISTADO 5, 2016)

Apesar de, em sua maioria, não terem recebido capacitações, professoras, diretoras e conselheiro entrevistados demonstraram interesse pelos cursos e eventos sobre o PNAE, ressaltando sua importância para todos os atores envolvidos na implementação do programa. O alinhamento e continuidade da capacitação de todos os atores que atuam no PNAE encontra amparo na literatura (SCARPARO et al, 2013; SANTOS et al, 2013).

Eu acho, pra mim, principalmente [importante receber capacitação], porque quando vem qualquer fiscalização, eles não vão nas meninas [merendeiras]. Eles questionam é comigo. Eu mesma, por nunca ter feito uma capacitação, às vezes alguma coisa fica errada, mas não por querer. É por falta mesmo de conhecimento. (ENTREVISTADO 1, 2016)

Só se realiza realmente um trabalho de uma alimentação favorável, se houver uma equipe, todo mundo trabalhando junto, todo mundo acreditando, todo mundo motivando. Então, para isso, eu acho que todo mundo tem que conhecer. (ENTREVISTADO 5, 2016)

Social de Transporte (Sest) (BRASIL. Disponível em: < www.senado.leg.br $>$. Acesso em 22 de novembro de 2016). 
As capacitações, elas são importantes, mas deveriam ser mais frequentes e mais abrangentes. Principalmente para servente, para diretora, professor. Eu sinto falta disso. Onde tem um diretor, a aprendizagem dele tem que ser geral sobre a unidade. Ele tem que saber [...] o que é que está chegando, o que é que está fazendo. [...] Eu acho que não é só o nutricionista que tem que ser capacitado. O responsável técnico tem que ser sim, mas eu acho que tem que capacitar gestor, tem que capacitar secretário, tem que capacitar pregoeiro, tem que capacitar diretor de escola. (ENTREVISTADO 8, 2016)

Quando questionados acerca das capacitações referentes ao PNAE, apenas um dos entrevistados citou o curso do programa Formação pela Escola. Esse curso é acessível, voltado para a capacitação de todos os atores do PNAE e poderia suprir as carências de capacitação para diretores, professores e conselheiros. O fato de não ser conhecido pela maior parte dos entrevistados pode indicar que a implementação do FPE apresenta dificuldades em Minas Gerais, ou que sua divulgação não é feita de maneira eficiente no estado.

Eu mesmo fiz uma formação em EAD sobre quilombolas, sobre cardápio específico para quilombolas. Foi ano passado, mas esse é para quem está cadastrado na plataforma, para quem já foi ao FNDE. As pessoas também não têm acesso a isso. Por exemplo, um diretor de escola não sabe o que é que é um Formação pela Escola. Eu sei porque eu fui lá. [...] O Formação pela Escola foi importante, mas eu acho que deveria chegar a um público que precisa também e esclarecer melhor as informações. (ENTREVISTADO 8, 2016)

Para além disso, os entrevistados reconheceram como capacitação os eventos realizados pelo FNDE e pelo Cecane, ambos direcionados aos nutricionistas, bem como os cursos dedicados às merendeiras, oferecidos pelas prefeituras municipais. Essas capacitações foram avaliadas, de modo geral, como positivas, apesar de apresentarem alguns problemas e, segundo os entrevistados, serem incrementais, não trazerem muitas novidades. Tanto os cursos oferecidos pelo FNDE, quanto aqueles oferecidos pelo Cecane, tiveram uma percepção semelhante por parte dos entrevistados. Para eles, os cursos de âmbito nacional apresentam pouca aderência à realidade municipal, ficando um abismo entre teoria e prática.

Foi um curso muito bom [Formação pela Escola], apesar de que eu acho que teoria é uma coisa, prática é outra. Sei da importância do curso, mas eu acho que teria que estar, sabe, as pessoas teriam que estar na prática pra entender umas questões. Então, 
a capacitação é boa, mas eu acho que as pessoas têm que enxergar um pouco a prática. (ENTREVISTADO 8, 2016)

Eficiente não é [capacitação]. É, assim... Não bate muito com a realidade dos fatos não. Lá, quando você está numa roda de conversa e um começa a falar com o outro, aí sim você começa a perceber. Mas o que eles [facilitadores nas capacitações] explicam, assim é mais voltado para as cidades maiores. [...] Eu não sei se é porque eles não visitam, não ficam próximos do que acontece "na real". Não sei... Eu acho que eles não andam nessas cidades para saber realmente. [...] Então é questão de mudança, de eles irem visitar os locais pra saber que jeito que é. Aí eu acho que dava. E também fazer regionalizado. O que acontece aqui em Minas, é diferente do que acontece com amigas minhas que são nutricionistas em Goiás. (ENTREVISTADO 11, 2016)

Apesar dos problemas apontados, os cursos oferecidos pelo FNDE e Cecanes foram definidos como importantes e úteis pelos entrevistados capacitados, principalmente no que diz respeito à abordagem de informações administrativas, como aquelas referentes ao registro de preço e aquisição de gêneros da agricultura familiar. Essas informações são claramente destinadas aos nutricionistas, que se responsabilizam por todo o trâmite burocrático do programa. Outro ponto de destaque positivo apontado pelos entrevistados foram as trocas de experiências que acontecem entre os participantes das capacitações, muitas vezes mais estimulantes que os conteúdos dos cursos e palestras ministrados.

\footnotetext{
Capacitações oferecidas a mim foram as realizadas pelo Cecane. Foram excelentes e contribuíram muito em questões como aquisição de produtos da agricultura familiar e elaboração de cardápios. [...] A troca de experiência com profissionais de outros municípios foi muito importante. Através do diálogo percebemos soluções já utilizadas que podem se adequar ao município, tais como conhecer novas preparações que podem ser utilizadas no cardápio. (ENTREVISTADO 4, 2016)
}

As capacitações, elas têm ajudado. Por exemplo, foi através de capacitação que o município está respeitando a questão do preço de aquisição da agricultura familiar. (ENTREVISTADO 8, 2016)

Contrariando o que foi encontrado na literatura (HONÓRIO, BATISTA, 2015), os resultados desta pesquisa não apontam para o despreparo dos nutricionistas para atuarem no programa de alimentação escolar, a despeito dos relatos que comprovam a grande quantidade de atribuições imputadas a eles. É notável que os nutricionistas exercem o papel mais atuante no PNAE, uma vez que é de sua responsabilidade não apenas a elaboração dos cardápios 
como também toda a questão administrativa e burocrática que envolve o programa. Sendo assim, o fato de serem os atores foco das capacitações do FNDE e dos Cecanes pode justificar a adequação desses profissionais às atribuições do cargo ocupado.

No caso das capacitações oferecidas às merendeiras, ficou claro pela fala dos entrevistados que o foco são questões práticas, que envolvem o dia a dia dessas profissionais nas cozinhas das escolas. As capacitações são presenciais, realizadas pelos nutricionistas das prefeituras e tratam desde questões de desperdício e adequação dos cardápios, até a segurança alimentar. Segundo os relatos, as merendeiras já conhecem boa parte do que é apresentado nos cursos, mas o reforço das informações é importante para a manutenção da qualidade do serviço. É notável que essas profissionais absorvem de forma mais natural as informações relacionadas à segurança alimentar, como higienização e manuseio dos alimentos. Entretanto, muitas vezes é sua prática que determina como o programa será implementado na escola, já que, partindo de sua experiência, elas alteram medidas formalmente recomendadas para o preparo das refeições para adequação à demanda, podem interferir de forma direta nos modos de preparo dos alimentos, nas quantidades e nas formas de servir.

É tudo muito bem explicado. No último curso, ela [nutricionista] colocou o cardápio do dia, aí ela foi explicar o que significam aquelas siglas: a proteína, vitaminas, tudo muito bem explicadinho. A gente tem a chance de falar do nosso dia a dia. Alguma dúvida, ela tira. E ela está sempre presente na escola. [...] E no dia a dia, a gente já aplica [os conhecimentos do curso]. Eu faço o que eu gosto, eu gosto de cozinha, então a gente já cozinha com amor. O curso, é mais um incentivo, um aperfeiçoamento maior. (ENTREVISTADO 3, 2016)

Muito bom, vão muitos professores bons, ensinam a gente muita coisa. Ensinam como manusear os alimentos, como a gente conduzir os alimentos e como a gente se portar. Muito bons os cursos. A gente é obrigado a fazer. A gente é obrigada a fazer, mas é um obrigado bom pra gente, porque o curso é excelente. (ENTREVISTADO 7, 2016)

A nutricionista mesmo, ela faz capacitação, e quando tem, ela chama diretor, chama as merendeiras, outras pessoas que vêm na escola também, que trabalham na escola e que queiram fazer capacitação. Aí tem o curso, tem manipulação dos alimentos, como proceder, como fazer. Ela ensina o que pode ser feito, as misturas que podem ser feitas, para não desperdiçar e economizar o máximo possível. (ENTREVISTADO 10, 2016) 
Normalmente, eu dou curso com o Senar, porque o Senar tem os instrutores, aí vem, compra tudo quanto é produto que precisar. Aí vão turmas a cada 12 cantineiras, ficam a semana inteira fazendo curso. Pra atualizar mesmo, saber o jeito certo de higienizar, o jeito certo de cortar... [...] Tudo prático! Teórico elas não... Elas não prestam muita atenção, na verdade. Prático é mais eficaz. [...] Todas eu visito, entrego apostila, explico, mas a prática é melhor. (ENTREVISTADO 11, 2016)

O relato dos entrevistados no que se refere às capacitações oferecidas às merendeiras reforça a literatura utilizada nesta pesquisa no que tange a teoria dos burocratas de nível de rua e o viés bottom-up do programa. São evidentes as necessárias adequações que sofrem as políticas públicas quando de sua implementação. (LIPSKY, 2010; BARDACH, 1979; PRESSMAN, WILDAVSKY, 1984; LINDER, PETERS, 1987).

O quadro a seguir demonstra, de forma resumida, os pontos relevantes da análise da terceira categoria, relacionando-os aos objetivos específicos da pesquisa.

Quadro 10 - Relação da Terceira Categoria com o Objetivo Específico Relacionado $3^{\circ}$ Categoria de Análise - Capacitações sobre o PNAE

\begin{tabular}{|c|c|}
\hline & $3^{\circ}$ Categoria de Análise - Capacitações sobre o PNAE \\
\hline & Objetivo Específico Relacionado \\
\hline & $\begin{array}{l}\text { Analisar como a capacitação de nutricionistas, conselheiros, merendeiras, professores e diretores } \\
\text { escolares influencia a implementação do programa }\end{array}$ \\
\hline & As capacitações são voltadas principalmente para nutricionistas e merendeiras. \\
\hline 冚 & $\begin{array}{l}\text { As capacitações foram avaliadas, de modo geral, como positivas, apesar de apresentarem alguns } \\
\text { problemas e, segundo os entrevistados, não trazerem muitas novidades. Sua utilidade se dá, } \\
\text { principalmente, no que diz respeito à abordagem de informações administrativas, como aquelas } \\
\text { referentes ao registro de preços e aquisição de gêneros da agricultura familiar. }\end{array}$ \\
\hline & $\begin{array}{l}\text { Os cursos de âmbito nacional apresentam pouca aderência à realidade municipal, ficando um abismo } \\
\text { entre teoria e prática. }\end{array}$ \\
\hline & $\begin{array}{l}\text { Apesar das capacitações, é notável que é a prática do dia a dia o fator determinante na } \\
\text { implementação do programa na escola. }\end{array}$ \\
\hline & $\begin{array}{l}\text { Quando há apoio de algum ente externo às prefeituras - universidades, associações, organizações não } \\
\text { governamentais, dentre outros - as capacitações ocorrem com maior frequência, além de abordarem } \\
\text { assuntos de interesse direto do grupo a ser capacitado. }\end{array}$ \\
\hline
\end{tabular}

Fonte: elaborado pela autora. 


\subsubsection{Escala de Capacitação}

Os resultados encontrados na análise das entrevistas motivaram a elaboração de uma escala para investigar, de forma objetiva, a efetividade das capacitações para implementação do PNAE em estados e municípios. Trata-se de proposta de modelo que poderá ser utilizado em pesquisas futuras para contribuir tanto com a produção acadêmica, quanto para o aprimoramento das capacitações ofertadas sobre o programa.

Dos resultados das entrevistas emergiram quatro pontos importantes acerca das capacitações, que foram considerados como categorias de análise: frequência das capacitações, temas de interesse para o capacitado, aplicação dos conhecimentos adquiridos no dia a dia e a multiplicação dos conhecimentos adquiridos pelo capacitado para seus pares. A ideia é que essas categorias sejam avaliadas pelo próprio capacitado - atores que atuam na implementação do PNAE em estados e municípios, seguindo uma escala.

Em se tratando de uma avaliação feita pelo próprio capacitado, usar o modelo de Likert (1932) para dar suporte metodológico à escala parece adequado. Em seus estudos, o autor buscou um método simples para medir as atitudes sociais, transformando as características qualitativas em ponto de vista matemático (Likert, 1932). O modelo de escala proposto por ele é bastante utilizado em pesquisas de opinião, uma vez que uma de suas ideias é que as atitudes, inatas ou aprendidas, não são elementos rígidos e inflexíveis de personalidade, mas tão somente um intervalo dentro do qual essas atitudes se encaixam (Likert, 1932). Sendo assim, é possível criar intervalos dentro dos quais as opiniões das pessoas se ajustam.

O modelo que se propõe aqui apresenta quatro questões, cada uma correspondendo a uma categoria de análise, cujas respostas variam em intervalos relacionados à concordância do respondente às indagações propostas. Cada intervalo corresponde a um valor, que variam 
de um a cinco. Nesse caso, quanto mais altas as notas, mais positiva é a percepção do entrevistado acerca da categoria. O quadro a seguir apresenta essa relação.

Quadro 11 - Escala de Capacitações

\begin{tabular}{|c|c|c|c|c|c|c|}
\hline \multirow{2}{*}{$\begin{array}{l}\text { Categorias de } \\
\text { Análise }\end{array}$} & \multirow{2}{*}{ Questões } & \multicolumn{5}{|c|}{ Escala } \\
\hline & & 1 & 2 & 3 & 4 & 5 \\
\hline Frequência & $\begin{array}{l}\text { As capacitações } \\
\text { acontecem com } \\
\text { frequência } \\
\text { suficiente para a } \\
\text { boa execução do } \\
\text { programa. }\end{array}$ & $\begin{array}{l}\text { Discordo } \\
\text { totalmente }\end{array}$ & Discordo & Indiferente & Concordo & $\begin{array}{l}\text { Concordo } \\
\text { totalmente }\end{array}$ \\
\hline $\begin{array}{l}\text { Temas de } \\
\text { Interesse do } \\
\text { Capacitado }\end{array}$ & $\begin{array}{c}\text { Os temas tratados } \\
\text { na capacitação são } \\
\text { de meu interesse. }\end{array}$ & $\begin{array}{l}\text { Discordo } \\
\text { totalmente }\end{array}$ & Discordo & Indiferente & Concordo & $\begin{array}{l}\text { Concordo } \\
\text { totalmente }\end{array}$ \\
\hline $\begin{array}{l}\text { Aplicação dos } \\
\text { conhecimentos } \\
\text { adquiridos }\end{array}$ & $\begin{array}{c}\text { Os conhecimentos } \\
\text { adquiridos na } \\
\text { capacitação foram } \\
\text { aplicados em meu } \\
\text { trabalho. }\end{array}$ & $\begin{array}{l}\text { Discordo } \\
\text { totalmente }\end{array}$ & Discordo & Indiferente & Concordo & $\begin{array}{l}\text { Concordo } \\
\text { totalmente }\end{array}$ \\
\hline $\begin{array}{l}\text { Multiplicação } \\
\text { dos } \\
\text { conhecimentos } \\
\text { adquiridos }\end{array}$ & $\begin{array}{c}\text { Consegui transmitir } \\
\text { aos meus colegas } \\
\text { os conhecimentos } \\
\text { que adquiri na } \\
\text { capacitação. }\end{array}$ & $\begin{array}{l}\text { Discordo } \\
\text { totalmente }\end{array}$ & Discordo & Indiferente & Concordo & $\begin{array}{l}\text { Concordo } \\
\text { totalmente }\end{array}$ \\
\hline
\end{tabular}

Fonte: elaborado pela autora com base no modelo de Likert (1932).

De acordo com a escala apresentada, quanto mais alta for a nota dada pelo ator capacitado ao conjunto das categorias, espera-se que maior seja o impacto da capacitação em suas atividades de trabalho e, consequentemente, na implementação do PNAE. As categorias podem tanto ser analisadas em conjunto quanto individualmente, visando o atendimento dos objetivos do programa. Os resultados provenientes da aplicação do questionário podem ajudar na identificação dos problemas das capacitações. Por exemplo, se um entrevistado avaliar a categoria frequência com uma nota abaixo de três, mas avaliar as demais categorias com notas superiores a três, a conclusão será de que apesar de a frequência das capacitações ser insuficiente, quando elas acontecem, são efetivas. Nesse caso, poderia haver indicação para o 
gestor de diluir os temas em mais capacitações, para que elas sejam constantes e motivem o capacitado (HONÓRIO, BATISTA, 2015; SCARPARO et al, 2013; SANTOS et al, 2013). Por outro lado, se a categoria referente ao tema de interesse for pontuada com uma nota inferior a três, por exemplo, pode-se considerar a necessidade de construção participativa das capacitações, para que essas sejam efetivamente voltadas aos interesses dos capacitados (BANDEIRA, 2012; LEITE et al, 2011) e contribuam para o alcance dos objetivos do programa.

Para se comprovar a eficiência das capacitações e o atendimento aos objetivos do PNAE, os resultados obtidos na escala podem ser confrontados com as informações objetivas sobre o programa. Essas informações são obtidas, controladas e publicadas pelo FNDE em diferentes circunstâncias: desde o acompanhamento da compra da agricultura familiar até a prestação de contas dos recursos aplicados no programa. Dentre essas informações, para fins de aferição da eficiência das capacitações, serão consideradas as seguintes: utilização de pelo menos $30 \%$ do recurso federal repassado para a aquisição de gêneros alimentícios com a compra itens da agricultura familiar (Disponível em $\langle\underline{w w w . f n d e . g o v . b r}>$. Acesso em 26 de outubro de 2016); adimplência na prestação de contas avaliada pelo CAE; resposta aos questionários do PNAE no Sistema de Gestão de Prestação de Contas (SIGPC) ${ }^{11}$ (Disponível em $\langle\underline{w w w . f n d e . g o v . b r}>$. Acesso em 26 de outubro de 2016).

Os valores de compra da agricultura familiar são publicados no site do FNDE e estão atualizados até o ano de 2014. As respostas aos questionários do PNAE no SIGPC podem ser consultadas no acesso público no site do FNDE e são de responsabilidade das prefeituras e dos conselhos de alimentação. As questões são referentes às exigências do PNAE, segundo a Lei 11.947 (BRASIL, 2009), tais como a compra de produtos de agricultura familiar;

\footnotetext{
${ }^{11}$ Os modelos de questionários do PNAE no SIGPC estão apresentados nos anexos deste estudo.
} 
contratação de nutricionistas para elaboração dos cardápios; inclusão da educação alimentar e nutricional (EAN) nos currículos escolares; atuação dos conselhos de alimentação escolar.

Para que se tenha a maior acurácia possível da eficiência das capacitações, a aplicação das questões da escala de capacitação deve ser feita após a avaliação dos dados objetivos oficiais de cada município. Esses mesmos dados deverão ser novamente analisados após a realização da capacitação, oferecendo assim a possibilidade de comparar as informações antes e depois.

Este capítulo expôs os resultados e discussões da fase de coleta de dados explicitada na metodologia da pesquisa. 


\section{CONSIDERAÇÕES FINAIS}

Esta dissertação buscou investigar como as capacitações dos atores envolvidos no Programa Nacional de Alimentação Escolar - PNAE, influenciam a implementação do programa e se conectam aos objetivos pretendidos por ele em três municípios do estado de Minas Gerais. Para isso, a investigação foi orientada para

- descrever como ocorre a implementação do PNAE nos municípios mineiros;

- analisar como a capacitação de nutricionistas, conselheiros, cozinheiros, professores e diretores escolares influencia a implementação do programa;

- investigar o alcance dos objetivos do programa nos municípios selecionados.

O estudo de casos múltiplos foi conduzido em três municípios mineiros. As entrevistas realizadas com implementadores do PNAE comprovam a teoria dos burocratas de nível de rua (LIPSKY, 2010), reforçando que nesta fase do ciclo de políticas públicas - implementação - a interferência do implementador é irremediável (PRESSMAN, WILDAVSKY, 1984). Os cursos de capacitação sobre o programa podem alinhar informações e adequar a implementação à política elaborada, mas não se mostraram capazes de inibir a interferência do implementador. Os implementadores lidam com os problemas do dia a dia, que nem sempre podem ser previstos quando da elaboração da política. Além disso, a implementação de políticas públicas esbarra em um ponto-chave, que é o comportamento humano (OLLAIK, MEDEIROS, 2011; LINDER, PETERS, 1987).

Sob o ponto de vista dos burocratas de nível de rua do PNAE, pode-se concluir que, de modo geral, a implementação do programa acontece de acordo com a legislação vigente, seja quanto às questões relativas à educação alimentar e nutriciona (EAN), seja quanto à oferta de alimentos. A influência dos implementadores, nesse caso, interfere pontualmente no processo de implementação do programa. No caso da EAN, os resultados mostraram que existe 
preocupação nas escolas em tratar do assunto, ainda que não haja, de forma contundente e expressiva, seu enquadramento curricular. As campanhas sobre obesidade e alimentação saudável realizadas nas escolas se mostraram os instrumentos pedagógicos mais relevantes de EAN, juntamente com a oferta de alimentos. Essas campanhas são bons exemplos comprobatórios da interferência dos implementadores em vários aspectos: a quantidade de alimentos servida pelas merendeiras acaba sendo uma das causas das campanhas; o engajamento das diretoras em EAN é fundamental para o sucesso dessas ações; o envolvimento de nutricionistas dá credibilidade às ações, mas não acontece com muita frequência.

Outro fator que se mostrou fundamental ao sucesso da implementação é a influência dos pais nos hábitos alimentares das crianças. Os resultados apontam para o necessário engajamento dos pais nas questões de EAN para que as iniciativas encontrem eco dentro e fora das escolas. Apesar de não serem implementadores diretos do PNAE, os pais são os principais reforçadores do comportamento das crianças e seu posicionamento quanto às questões da educação dos filhos pode ser decisivo.

No que tange a oferta de alimentos, pode-se dizer que ela acontece de acordo com a legislação pertinente: as escolas ofertam gêneros alimentícios naturais e saudáveis oriundos da agricultura familiar, que é reconhecida pela qualidade de seus produtos e frequência das entregas; a compra dos alimentos é feita cumprindo-se os requisitos licitatórios. A influência dos implementadores, nesse caso, acontece nas cozinhas, quando do preparo dos alimentos. Nem sempre, por exemplo, as fichas técnicas e quantidades propostas pelos nutricionistas para o preparo dos alimentos é seguida pelas merendeiras. Conclui-se, portanto, que os implementadores compreendem a necessidade de se fazer os ajustes para a adequação da implementação à realidade de cada escola. 
Em relação à influência das capacitações na implementação do programa, pode-se dizer que elas são expressivas quando se trata de assuntos administrativos, como o registro de preços e detalhes sobre a aquisição de gêneros da agricultura familiar. Por outro lado, seu conteúdo se mostrou pouco inovador para os atores capacitados, apresentando pouca conexão à realidade dos municípios. A oferta de capacitações é feita preferencialmente para nutricionistas e merendeiras, fator que pode contribuir para o baixo engajamento de outros implementadores no programa, principalmente em EAN. Professoras e diretoras ficam alheias às capacitações e são elas as responsáveis por organizar e difundir a educação alimentar nos ambientes escolares. Os resultados das entrevistas mostraram que em municípios onde há apoio de universidades, associações, organizações não governamentais, dentre outros, as capacitações acontecem com maior frequência e os assuntos abordados têm maior aceitação entre os implementadores. Essas parcerias podem indicar um modelo de sucesso para a capacitação de atores do PNAE. Diante disso, conclui-se, ratificando a literatura (LEITE et al, 2011; BANDEIRA, 2012; SCARPARO et al, 2013; SANTOS et al, 2013), que as capacitações precisam ser mais bem pensadas, tanto em relação a seu conteúdo quanto à sua frequência, para atender às necessidades dos implementadores. Entretanto, ainda que isso aconteça, a prática do dia a dia desses profissionais dificilmente será integralmente adequada já que a forma com que as pessoas compreendem a política e se engajam com sua implementação é determinante para seu sucesso.

Quanto ao alcance dos objetivos do programa, confrontam-se as exigências legais do PNAE (BRASIL, 2009) aos resultados desta pesquisa. Duas das exigências se mostraram totalmente alcançadas: a compra de produtos da agricultura familiar cumpre os requisitos legais; os cardápios são elaborados e orientados por nutricionistas. Em relação à inclusão da educação alimentar e nutricional nos currículos escolares, pode-se dizer que há cumprimento parcial desse objetivo. O tema ainda não demonstra ter a relevância necessária nas escolas 
para que se proponha seu aprofundamento e efetiva inclusão na grade curricular. Apesar disso, a discussão do assunto em algumas disciplinas, as campanhas e a oferta de alimentos dão conta do cumprimento parcial da exigência. Algumas dificuldades de implementação comprometem o sucesso da EAN nas escolas: sobrecarga de responsabilidades atribuídas aos nutricionistas, dificultando sua maior participação nas ações de EAN nas escolas; engajamento heterogêneo dos atores na implementação da EAN; influência familiar nos hábitos alimentares. Quanto à atuação dos conselhos de alimentação escolar, foi clara sua atuação em relação à fiscalização da oferta de alimentos, o que cumpre com as exigências do programa. Entretanto, sua atuação frente às questões de EAN, estabelecendo o controle social dessas atividades, foi inconclusiva nesta pesquisa.

O PNAE é uma política nacional cuja implementação se dá em contexto municipal. Essa informação por si só já indicaria que há influência dos implementadores no programa. $\mathrm{O}$ alinhamento dos objetivos e especificidades do programa pode acontecer por meio de capacitações, que podem fornecer informações e reflexões relevantes, sem terem, entretanto, a capacidade de inibir a interferência do implementador. Esta pesquisa mostrou exatamente isso: as capacitações podem interferir até certo ponto na implementação, mas não são capazes de mudar essencialmente nem as pessoas que atuam no programa, nem os hábitos e cultura regionais. Essa visão bottom-up mostra que os objetivos do programa têm sido parcialmente cumpridos e que a principal lacuna percebida é referente à EAN. Nesse caso, é relevante notar que os atores que naturalmente promovem essas ações nas escolas, professoras e diretoras, não são incluídas nas capacitações, o que reforça a necessidade de ofertas constantes e alinhadas às necessidades dos implementadores.

Os resultados aqui apresentados foram alcançados a despeito de uma limitação da pesquisa. Houve grande dificuldade em conseguir entrevistas com membros do CAE nos 
municípios. Muitos não responderam aos contatos feitos por e-mail ou telefone e alguns se recusaram a colaborar com a pesquisa.

Em relação às contribuições da pesquisa, além de colaborar com a apresentação de análise inédita nos estudos sobre o PNAE, ela apresentou proposta de escala de capacitação, que poderá ser aplicada pelo FNDE para que haja melhor direcionamento das estratégias de capacitação sobre o programa. A escala, elaborada a partir dos resultados das entrevistas, pode também ser aplicada em pesquisas futuras, para avaliação de sua eficiência. Além disso, propõe-se como pesquisas futuras a aplicação da mesma motodologia utilizada neste trabalho em uma amostra mais ampla; um estudo aprofundado sobre a influência dos pais nos hábitos alimentares dos filhos e em que medida isso interfe na implementação do PNAE. 


\section{REFERÊNCIAS}

ABICALIL, C.A. O federalismo e o Sistema Nacional de Educação: uma oportunidade fecunda. Retratos da Escola. Brasília, v. 6, n. 10, p. 21-37, jan./jun. 2012.

BANDEIRA, L.M. Formação a distância para conselheiros de alimentação escolar: elaboração, aplicação e avaliação. 2012. 168 f. Dissertação (Mestrado em Nutrição) Programa de Pós Graduação em Nutrição Humana, Universidade de Brasília, Brasília, 2012.

BARDACH, E. The implementation game. Cambridge, MA: MIT Press, 1979.

BARDIN, L. Análise de Conteúdo. Press Universitaires de France, 1977.

BELIK, W.; CHAIM, N. O programa de alimentação escolar e a gestão municipal: eficiência administrativa, controle social e desenvolvimento local. Revista de Nutrição. Campinas, v. 22, n. 5, p. 595-607, set./out. 2009.

BRASIL. Constituição da República Federativa do Brasil de 1988, Brasília, DF, 1988.

CONTROLADORIA GERAL DA UNIÃO. Disponível em: 〈www.cgu.gov.br〉. Acesso em 05 de dezembro de 2016.

Relatório de Fiscalização n ${ }^{\circ}$ V01016 do Programa de Fiscalização em Entes Federativos. Controladoria Geral da União, Brasília, DF, 2015. Disponível em: <www.cgu.gov.br>. Acesso em 05 de dezembro de 2016. 
FUNDO NACIONAL DE DESENVOLVIMENTO DA EDUCAÇÃO. Edital de convocação 01/2013 CGPAE de 01 de agosto de 2013. Edital de Convocação para Habilitação de Instituições Federais de Ensino Superior (IFES) para Formação de Parcerias e Implementação de Ações de Apoio ao Programa Nacional de Alimentação Escolar (PNAE) como Unidades Acadêmicas Especializadas (UAE) ou Centros Colaboradores em Alimentação e Nutrição Escolar (CECANE). Fundo Nacional de Desenvolvimento da Educação, Brasília, DF, 01 ago. 2013. Disponível em: 〈www.fnde.gov.br〉. Acesso em 02 de fevereiro de 2016.

Programa Nacional de Alimentação Escolar. Disponível em:

<www.fnde.gov.br > Vários acessos.

Sistema de Informação do Programa Formação pela Escola. Disponível em: 〈sistemas.fnde.gog.br/sife>. Acesso em 05 de janeiro de 2016.

INSTITUTO BRASILEIRO DE GEOGRAFIA E ESTATÍSTICA. Produto Interno

Bruto dos Municípios 2010-2013. Disponível em: 〈www.ibge.gov.br $>$. Acesso em 29 de janeiro de 2016.

INSTITUTO NACIONAL DE ESTUDOS E PESQUISAS EDUCACIONAIS

ANÍSIO TEIXEIRA. Censo Escolar 2014. Disponível em:

<www.dataescolabrasil.inep.gov.br >. Acesso em 10 de março de 2016.

Lei n. 8.666, de 21 de junho de 1993. Institui normas para licitações e contratos da Administração Pública. Diário Oficial [da República Federativa do Brasil], Brasília, DF, n. 116, 22 jun. 1993. Seção I, p. 8269.

Lei n. 10.520, de 17 de julho de 2002. Institui no âmbito da União, Estados, Distrito Federal e Municípios, nos termos do art. 37, inciso XXI, da Constituição Federal, modalidade de licitação denominada pregão, para aquisição de bens e serviços comuns. Diário Oficial [da República Federativa do Brasil], Brasília, DF, n. 137, 18 jul. 2002. Seção I, p. 1.

Lei n. 11.947, de 16 de junho de 2009. Dispõe sobre o atendimento da alimentação escolar e do Programa Dinheiro Direto na Escola aos alunos da educação básica. Diário Oficial [da República Federativa do Brasil], Brasília, DF, n. 113, 17 jun. 2009. Seção I, p. $2-4$. 
Ministério da Educação. Fundo Nacional de Desenvolvimento da Educação.

Resolução n. 26, de 17 de junho de 2013. Dispões sobre o atendimento da alimentação escolar aos alunos da educação básica no âmbito do Programa Nacional de Alimentação Escolar PNAE. Diário Oficial [da República Federativa do Brasil], Brasília, DF, n. 115, 18 jun. 2013. Seção I, p. 7-12.

Ministério da Saúde. Ministério da Educação. Portaria Interministerial n. 1.010, de 08 de maio de 2006. Institui as diretrizes para a promoção da alimentação saudável nas Escolas de educação infantil, fundamental e nível médio das redes públicas e privadas, em âmbito nacional. Diário Oficial [da República Federativa do Brasil], Brasília, DF, n. 87, 09 mai. 2006. Seção I, p. 70.

SENADO FEDERAL. Sistema S. Disponível em: < www.senado.leg.br >. Acesso em 22 de novembro de 2016.

CARDOSO, S; SANTOS, O.; NUNES, C.; LOUREIRO, I. Escolhas e hábitos alimentares em adolescentes: associação com padrões alimentares do agregado familiar. Revista Portuguesa de Saúde Pública. Lisboa, v. 33, n. 2, p. 128-136, 2015.

CHUPROSKI, P.; TSUPA, P.A.; FUJIMORI, E.; RIBEIRO, R.P.P.; MELLO, D.F. Práticas alimentares e situação social de famílias de crianças desnutridas. Revista da Escola de Enfermagem da USP. São Paulo, v. 46, n. 1, p. 52-9, 2012.

EASTON, D. A Framework for political analysis. Englewood Cliffs: Prentice Hall, 1965.

FREY, K. Políticas públicas: um debate conceitual e reflexões referentes à prática da análise de políticas públicas no Brasil. Planejamento e Políticas Públicas, Brasília, n. 21, p. 211$259,2000$.

GABRIEL, C.; CALVO, M.C.; OSTERMANN, R.; VASCONCELOS, F. Proposta e aplicabilidade de modelo para avaliação da gestão municipal do Programa Nacional de Alimentação Escolar. Caderno de Saúde Pública. Rio de Janeiro, v. 30, n. 8, p. 1731- 1744, ago. 2014.

HILL, M.; HUPE, P.. Implementing public policy. Londres: Sage Publications, 2002. 
HOGWOOD, B. W.; GUNN, L. A. Policy analysis for the real world. Oxford: Oxford University Press, 1984.

HONÓRIO, A.R.F; BATISTA, S.H. Percepções e demandas de nutricionistas da alimentação escolar sobre sua formação. Trabalho, Educação e Saúde, Rio de Janeiro, v. 13, n. 2, p. 473492, mai./ago. 2015.

HOOD, C. The Limits of Administration. Londres: Wiley, 1976.

HOWLETT, M.; RAMESH, M. PERL, A. Política Pública: seus ciclos e subsistemas - uma abordagem integradora. Rio de Janeiro: Elsevier, 2013.

KNEIPP, C.; HABITZREUTER, F; MEZADRI, T.; HÖFELMANN, D.A. Excesso de peso e variáveis associadas em escolares de Itajaí, Santa Catarina, Brasil. Ciência \& Saúde

Coletiva, Rio de Janeiro, v. 20, n.8, p.2411-2422, 2015.

KINGDON, J. W. Agendas, alternatives, and public policies. 2. ed. Nova York: Harper Collins College Publishers, 1995.

LASWELLL, H. D. Politics: who gets what, when and how. Cleveland: Meridian Books. 1936.

LEITE, C.L.; CARDOSO, R.C.V; GÓES, J.A.W.; FIGUEIREDO, K.V.N.A; SILVA, E.O; BEZERRIL, M.M.; VIDAL JUNIOR, P.O.; SANTANA, A.A.C. Formação para merendeiras: uma proposta metodológica aplicada em escolas estaduais atendidas pelo programa nacional de alimentação escolar em Salvador, Bahia. Revista de Nutrição, Campinas, v. 24, n.2, p. 275-285, mar./abr. 2011.

LIKERT, R. A Technique for the Measurement of Attitudes. New York: New York Univesrity, 1932.

LIMA, M.; MEDEIROS, J. Empreendedores de políticas públicas na implementação de programas governamentais. Revista de Administração Pública, Rio de Janeiro, v. 46, n.5, p.1251-270, set./out. 2012. 
LINDBLOM, C.E. The science of muddling through. Public Administration Review. Connecticut, v.19, n.2, Spring, p. 78-88. 1959.

LINDBLOM, C.E. Still muddling. Not yet through. Public Administration Review. Connecticut, v. 39, p. 517-526. 1979.

LINDER, S.H.; PETERS, B.G. Relativism, contingency and the definition of success in implementation research. Policy Studies Review, Urbana, v. 7, n. 1, p. 116-127, 1987.

LIPSKY, M. Street-level Bureaucracy: dilemmas of the individual in public services. 3 ed. New York: Rusell Sage Fundation, 2010.

MAZMANIAN, D.; SABATIER, P. Implementation and public policy. Glenview, Il.: Scott Foresman, 1983.

MAZZOTTI, A. Usos e abusos dos estudos de caso. Cadernos de Pesquisa. Rio de Janeiro, v. 36, n. 129, p. 637-652, set./dez. 2006.

MOORE, M.; KEARSLEY, G. Educação a Distância: uma visão integrada. São Paulo: Cengage Learning. 2008.

NAJAM, A. Learning from the literature on policy implementation: a synthesis perspective. Austria: International Institute for Applied Systems Analysis, 1995.

OLLAIK, L.; MEDEIROS, J. Instrumentos Governamentais: reflexões para uma agenda de pesquisas sobre implementação de políticas públicas no Brasil. Revista de Administraçãa Pública. Rio de Janeiro, v. 45, n.6, p.1943-67, nov./dez. 2011.

OLLAIK, L. A implementação da política nacional de museus e a democratização de acesso: estudo comparativo de três instrumentos governamentais. 2012. $248 \mathrm{f}$. Tese (Doutorado em Administração) - Programa de Pós Graduação em Administração, Universidade de Brasília, Brasília, 2012. 
OLIVEIRA, J.A.P. Desafios do planejamento em políticas públicas: diferentes visões e práticas. Revista de Administração Pública, Rio de Janeiro, v. 40, n. 1, p. 273-288, mar./abr. 2006.

O'TOOLE, L.J.Jr. Research on policy implementation: assessment and prospects. Journal of Public Administration Research and Theory, Georgia, v.10, n.2, p. 263-288, 2000.

PELISSOLI, L.; LOYOLLA, W. Aprendizado móvel (M-LEARNING): dispositivos e cenários. In: CONGRESSO INTERNACIONAL DE EDUCAÇÃO A DISTÂNCIA, 2004, Brasil. Atas... 2004, p. 3-6. Disponível em:

<http://www.abed.org.br/congresso2004/por/htm/074-TC-C2. htm>. Acesso em 29 de janeiro de 2016.

PRESSMAN, J.L.; WILDAVSKY, A. Implementation. 3 ed. Berkeley: University of California Press, 1984.

RUS PEREZ, J.R. Por que pesquisar implementação de políticas educacionais atualmente?. Educação \& Sociedade. Campinas, v. 31, n. 113, p. 1179-1193, out./dez. 2010.

SAETREN, H. Facts and Myths about Research on Public Policy Implementation: out-offashion, allegedly dead, but still very much alive and relevant. Policy Studies Journal, vol. 33 n. 4, p. 559-582, 2005.

SAMPAIO, A.B.M.; NOGUEIRA, T.L.; GRIGOLON, R. B.; ROMA, A.M.; PEREIRA, L.E; Dunker, K.L.L. Seletividade alimentar: uma abordagem nutricional. Jornal Brasileiro de Psiquiatria. Rio de Janeiro, v. 62, n. 2, p.164-70, abr./jun. 2013.

SANTOS, L.; CARVALHO, D.; REIS, A.; RAMOS, L.; FREITAS, M. Formação de coordenadores pedagógicos em alimentação escolar: um relato de experiência. Ciência \& Saúde Coletiva. Rio de Janeiro, v. 18, n. 4, p. 993-1000, abr. 2013.

SCARPARO, A.; OLIVEIRA, V.; BITTENCOURT, J.; RUIZ, E.; FERNANDES, P.; ZYS, J.; MOULIN, C. Formação para nutricionistas que atuam no programa nacional de alimentação escolar: uma avaliação de efetividade. Ciência \& Saúde Coletiva. Rio de Janeiro, v. 18, n. 4, p. 1001-1008, abr. 2013. 
SIMON, H. A. Administrative behavior: a study of decision-making processes in administrative organizations. 4ed. Nova York: Free Press, 1997.

SOUZA, C. Políticas Públicas: uma revisão da literatura. Sociologias, Porto Alegre, v. 8, n.16, p. 20-45, jul/dez 2006.

SOUZA, C. Estado da arte da pesquisa em políticas públicas. In: HOCHMAN, G.;

ARRETCHE, M.; MARQUES, E. (Org.). Políticas públicas no Brasil. Rio de Janeiro: Fiocruz, 2007, p. 65-86.

THIRY-CHERQUES, H.R. Saturação em pesquisa qualitativa: estimativa empírica de dimensionamento. Revista Brasileira de Pesquisa em Marketing, v. 3, set. 2009. Disponível em: 〈www.revistapmkt.com.br〉. Acesso em 30 de janeiro de 2016.

UNIVERSIDADE FEDERAL DE OURO PRETO (UFOP). Relatório parcial exercício 2014/2015 Cecane Ufop. Ouro Preto, mai. 2015.

VERGARA, S.C. Métodos de pesquisa em administração. São Paulo: Atlas, 2005.

YIN, R.K. Case Study Research: design and methods. 2 ed. Thousand Oaks: Sage Publications, 1994. 


\section{APÊNDICE A - ROTEIRO PARA ENTREVISTAS}

Nome:

Função:

Há quanto tempo na função:

Educação Alimentar e Nutricional

O que você entende sobre educação alimentar e nutricional?

Como se pode promover a educação nutricional na escola?

\section{$\underline{\text { Oferta de Alimentos }}$}

Na sua opinião, a oferta de alimentos é feita de forma adequada? Por que?

\section{Cursos de Capacitação}

Como você avalia as capacitações oferecidas a você?

Como o aprendizado das capacitações contribuiu no seu trabalho? 


\section{APÊNDICE B - TERMO DE CONSENTIMENTO}

$\mathrm{Eu}$,

RG de forma livre e esclarecida aceito participar do presente estudo e autorizo a pesquisadora Isabella Araújo Figueiredo, mestranda do Programa de Pós-Graduação Profissional em Gestão Pública da Faculdade UnB de Planaltina, FUP/UnB, cujo tema do projeto de pesquisa é Influência das Capacitações na Implementação do Programa Nacional de Alimentação Escolar em Minas Gerais, sob orientação da $\operatorname{Prof}^{a}$ Dr $^{\mathrm{a}}$ Annita Valléria Calmon Mendes, a utilizar-se das informações obtidas na entrevista da qual participo, por meio de gravador de voz e anotações escritas, respeitando aos critérios da ética de pesquisa onde está assegurado o total anonimato dos participantes. Para qualquer informação a respeito dessa pesquisa devo entrar em contato com a pesquisadora através do e-mail: isabellaaraujof@yahoo.com.br ou telefone: (61) 98172-1945. Declaro estar ciente desse termo do qual também recebi uma cópia e concordo com o acima exposto.

\section{Nome e assinatura do participante}

ISABELLA ARAÚJO FIGUEIREDO

Pesquisadora

Contatos da Pesquisadora:

E-mail: isabellaaraujof@yahoo.com.br

Telefone Celular: (61) 98172-1945 


\section{ANEXO A - MODELO DE QUESTIONÁRIO DO PNAE NO SIGPC - PREFEITURAS}

Questionário do PNAE 2015

*1) $\mathrm{O}$ município/estado/DF ofereceu complementação dos recursos financeiros transferidos pelo FNDE?

\section{(6) Sim \\ Não}

*2) Houve fornecimento de alimentação nas escolas durante 800 horas ou 200 dias letivos?

(•) Sim

(C) Não

Parcialmente

*3) Como foi realizado o fornecimento de alimentos nas escolas:

(c) entrega de gêneros alimentícios às escolas

repasse de recurso financeiro às escolas

entrega de gêneros alimentícios e repasse de recurso financeiro às escolas

*4) Houve contratação de empresa para o fornecimento de refeições nas escolas?

\section{(C) Sim \\ (*) Não}

*5) A EEx. adquiriu produtos orgânicos e/ou agroecológicos?

(•) Sim

(C) Não

*6) Houve a compra de gêneros alimentícios da agricultura familiar e/ou do Empreendedor Familiar Rural?

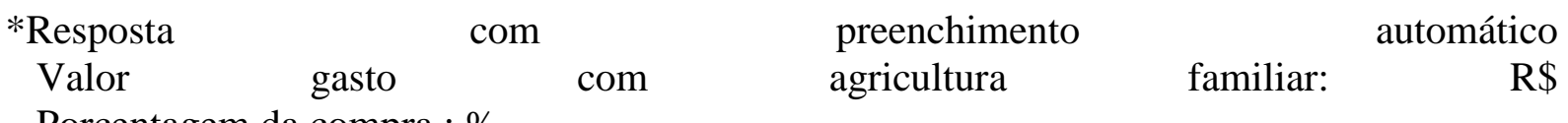

Porcentagem da compra : \%

Sim, foi executado o mínimo de $30 \%$ para aquisição de gêneros alimentícios da agricultura familiar e/ou do Empreendedor Familiar Rural ou suas organizações para a alimentação escolar.

Sim, porém não foi executado o percentual mínimo obrigatório de $30 \%$ do recurso 
executado para aquisição de gêneros alimentícios da agricultura familiar e/ou do Empreendedor Familiar Rural ou suas organizações para a alimentação escolar.

Não

*7) A forma de aquisição dos alimentos oriundos da Agricultura Familiar foi realizada por chamada pública?

\begin{tabular}{l|l} 
(-) Sim \\
(c) Não
\end{tabular}

*8) Havia Nutricionista responsável Técnico pelo programa na EEx.?

(•) Sim

C Não

*8.1) Havia Quadro Técnico de nutricionistas?

(*) Sim

Não

*8.1.1) O quadro técnico era composto por quantos nutricionistas?

01

*9) Havia cardápio elaborado para a alimentação escolar?

(•) Sim

C Não

*9.1) O cardápio elaborado foi cumprido?

Totalmente

(c) Parcialmente

Não foi cumprido

*9.1.1) Por que o cardápio Não foi cumprido?

$\ulcorner$ Problemas no processo de compras

$\Gamma \quad$ Falta de planejamento

$\ulcorner\quad$ Ausência de merendeiro (a)/cozinheiro (a)

$\ulcorner$ Irregularidade na entrega dos gêneros alimentícios nas escolas

$\ulcorner$ Estrutura inadequada da escola para a realização das preparações previstas no cardápio

『 Imprevistos tais como: falta de água, luz, gás, entre outros. 
*9.2) No cardápio estavam descritas as informações nutricionais, tais como: nome da preparação, ingredientes, calorias, macro e micronutrientes prioritários (carboidratos, proteínas e lipídios, Vitaminas A e C, Magnésio, Ferro, Zinco e Cálcio) e o percentual atendido das necessidades diárias?

\footnotetext{
C Sim

(*) Não
}

*9.3) O cardápio foi divulgado para a comunidade escolar em informativos, nas secretarias de educação e nas escolas, com as devidas informações nutricionais?
- Sim
C Não

*9.4) O cardápio informado apresentou 3 porções de frutas e hortaliças semanais?

\section{(-) Sim \\ Não}

*9.5) O cardápio apresentou a descrição da etapa/modalidade de ensino atendida (creche, pré-escola, ensino fundamental, ensino médio, EJA)?
(c) Sim
Não

*9.6) Havia cardápio diferenciado aos indígenas e/ou quilombolas, com preparações que respeitassem a cultura alimentar?
Sim
(c) Não
Não se aplica

*10) Foi aplicado teste de aceitabilidade?

\section{Sim \\ (c) Não}

*11) A EEx. implementou ações de controle de qualidade previstas no Termo de Compromisso?
(c) Sim
C Não

*12) Foi desenvolvida alguma atividade de educação Alimentar e Nutricional? 


\section{Sim}

Não

*12.1) Quais ações foram promovidas?

$\nabla$ oferta de alimentação adequada e saudável na escola;

$\nabla$ formação de pessoas envolvidas direta ou indiretamente com a alimentação escolar;

ॠ articulação das políticas municipais, estaduais, distritais e federais no campo da alimentação escolar;

$\sqrt{V}$ dinamização do currículo das escolas, tendo por eixo temático a alimentação e nutrição;

$\Gamma$ estímulo e promoção à utilização de produtos orgânicos e/ou agroecológicos e da sociobiodiversidade;

$\sqrt{\nabla}$ estímulo aos hábitos alimentares regionais e culturais saudáveis;

$\ulcorner$ outras:

*13) A EEx atende alunos na educação integral ou inscritos no Programa Mais Educação?

(*) Sim

C. Não

*13.1) A EEx ofertou, no mínimo, 3 refeições para os alunos da Educação Integral ou do Programa Mais Educação?
(c) Sim
C Não

*14) A EEx atende alunos de comunidades tradicionais indígenas e/ou quilombolas?

\section{(6) Sim \\ (C) Não}

*14.1) O cardápio respeita as especificidades culturais das comunidades tradicionais indígenas e/ou quilombolas?
Sim
(* Não

*15) A EEx atende alunos da modalidade Atendimento Educacional Especializado (AEE)?

$$
\begin{aligned}
& c \text { Sim } \\
& \bullet \text { Não }
\end{aligned}
$$


*16) O cardápio respeita as necessidades nutricionais específicas?

Sim

(C) Não

*17) O CAE dessa EEx. participou do acompanhamento da execução do PNAE?

(6) Sim

Não

*17.1) Quais foram as atividades:

visitas às escolas

$\nabla$

participação dos processos de compras dos gêneros alimentícios

$\sqrt{\checkmark}$ monitoramento e fiscalização a aplicação dos recursos financeiros

monitoramento e fiscalização do cumprimento das diretrizes da alimentação escolar

$\sqrt{\checkmark}$ monitoramento e fiscalização do cumprimento dos objetivos da alimentação escolar

$\checkmark$ análise da prestação de contas e emissão do parecer conclusivo

$\Gamma$ comunicação de irregularidades ao FNDE, aos órgãos de controle e ao Ministério Público

₹ elaboração e apresentação do Plano de Ação anual das atividades do CAE 


\section{ANEXO B - MODELO DE QUESTIONÁRIO DO PNAE NO SIGPC - CAE}

Relatório de Gestão

1) $\mathrm{O}$ município/estado/DF ofereceu complementação dos recursos financeiros transferidos pelo FNDE?
(6) Sim
C Não

2) Houve fornecimento de alimentação nas escolas durante 800 horas ou 200 dias letivos?
(6) Sim
(C) Não
Parcialmente

3) Como foi realizado o fornecimento de alimentos nas escolas:

- entrega de gêneros alimentícios às escolas

repasse de recurso financeiro às escolas

entrega de gêneros alimentícios e repasse de recurso financeiro às escolas

4) Houve contratação de empresa para o fornecimento de refeições nas escolas?
Sim
- Não

5) A EEx. adquiriu produtos orgânicos e/ou agroecológicos?
(6) Sim
C Não

6) Houve a compra de gêneros alimentícios da agricultura familiar e/ou do Empreendedor Familiar Rural?

- Sim, foi executado o mínimo de $30 \%$ para aquisição de gêneros alimentícios da agricultura familiar e/ou do Empreendedor Familiar Rural ou suas organizações para a alimentação escolar. 
Sim, porém não foi executado o percentual mínimo obrigatório de $30 \%$ do recurso executado para aquisição de gêneros alimentícios da agricultura familiar e/ou do Empreendedor Familiar Rural ou suas organizações para a alimentação escolar.

Não

7) A forma de aquisição dos alimentos oriundos da Agricultura Familiar foi realizada por chamada pública?

\begin{tabular}{l|l}
$\cdot$ & Sim \\
6 & Não
\end{tabular}

8) Havia Nutricionista Responsável Técnico pelo programa na EEx.?

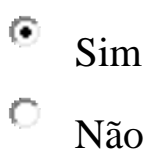

8.1) Havia Quadro Técnico de nutricionistas?

(6) Sim

(C) Não

Não sabe

9) Existia cardápio elaborado para a alimentação escolar?
(6) Sim
Não

9.1) Conforme observado pelo CAE, o cardápio elaborado foi cumprido?

Totalmente

(c) Parcialmente

Totalmente descumprido

9.1.1) Por que o cardápio não foi cumprido?

Problemas no processo de compras

Falta de planejamento

Ausência de merendeiro (a)/cozinheiro (a)

$\Gamma$ Irregularidade na entrega dos gêneros alimentícios nas escolas

Estrutura inadequada da escola para a realização das preparações previstas no 
cardápio

Imprevistos tais como: falta de água, luz, gás, entre outros.

9.2) No cardápio estavam descritas as informações nutricionais, tais como: nome da preparação, ingredientes, calorias, macro e micronutrientes prioritários (carboidratos, proteínas e lipídios, Vitaminas A e C, Magnésio, Ferro, Zinco e Cálcio) e o percentual atendido das necessidades diárias?

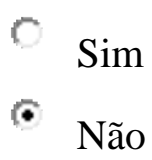

9.3) O cardápio foi divulgado para a comunidade escolar em informativos, nas secretarias de educação e nas escolas, com as devidas informações nutricionais?

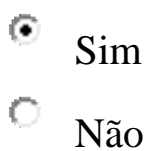

9.4) O cardápio informado apresentou 3 porções de frutas e hortaliças semanais?

\begin{tabular}{l|l} 
- & Sim \\
& Não
\end{tabular}

9.5) O cardápio apresentou a descrição da etapa/modalidade de ensino atendida (creche, préescola, ensino fundamental, ensino médio e EJA)?

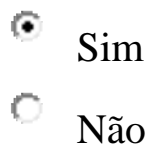

9.6) Havia cardápio diferenciado aos indígenas e/ou quilombolas, com preparações que respeitassem a cultura alimentar?

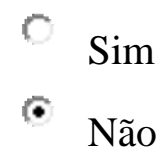

9.7) Havia cardápio para atendimento dos alunos com necessidade nutricionais específicas, tais como doença celíaca, diabetes, hipertensão, alergias e intolerâncias alimentares?

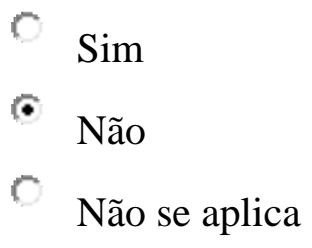

10) Foi aplicado teste de aceitabilidade? 
Sim

- Não

11) Quais aspectos relacionados às condições de armazenamento de gêneros alimentícios estavam adequadamente presentes nas escolas e/ou armazém central?

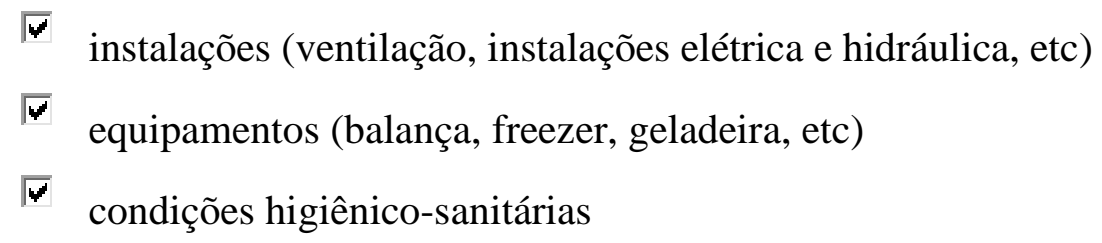

12) Conforme observado pelo $\mathrm{CAE}$, foi realizado, pela entidade executora, controle de estoque de forma adequada nas escolas e/ou no armazém?

(• Totalmente

Parcialmente

Não foi realizado adequadamente

13) Foi desenvolvida alguma atividade de Educação Alimentar e Nutricional?

\begin{tabular}{l|l}
$*$ & Sim \\
6 & Não
\end{tabular}

13.1) Quais ações foram promovidas?

『 oferta de alimentação adequada e saudável na escola;

$\nabla$ formação de pessoas envolvidas direta ou indiretamente com a alimentação escolar;

$\sqrt{\checkmark}$ articulação das políticas municipais, estaduais, distritais e federais no campo da alimentação escolar;

『 dinamização do currículo das escolas, tendo por eixo temático a alimentação e nutrição;

『 estímulo e promoção à utilização de produtos orgânicos e/ou agroecológicos e da sociobiodiversidade;

『 estímulo aos hábitos alimentares regionais e culturais saudáveis;

outras:

14) A EEx. atende alunos inscritos no Programa Mais Educação/Educação em Tempo Integral?

(6) Sim 
Não

14.1) A EEx. ofertou, no mínimo, três refeições do Programa Mais Educação?<smiles>C[SnH3]</smiles>

15) Quais itens de infraestrutura a EEx. disponibilizou ao CAE para a execução das suas atribuições:

$\nabla$ Local apropriado para reuniões

$\nabla$ Equipamentos de informática

『 Transporte para deslocamento dos conselheiros (reuniões, visitas às escolas, etc)

$\nabla$ Recursos humanos e financeiros para execução de atividades de apoio

$\Gamma \quad$ Nenhum item de infraestrutura foi oferecido

16) A EEx. forneceu ao CAE, quando solicitado, todos os documentos e informações referentes à execução do PNAE ao longo do ano?

(- Sempre

a maioria das vezes

raramente

nunca

17) Existiu Regimento Interno do CAE?
Sim
• Não

18) Existiu Plano de Ação anual (planejamento das atividades) do CAE?

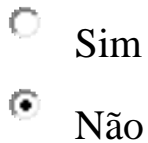

19) O Conselho realizou visitas às escolas?<smiles>[Mg][SnH3]</smiles>

19.1) Qual foi a periodicidade das visitas? 


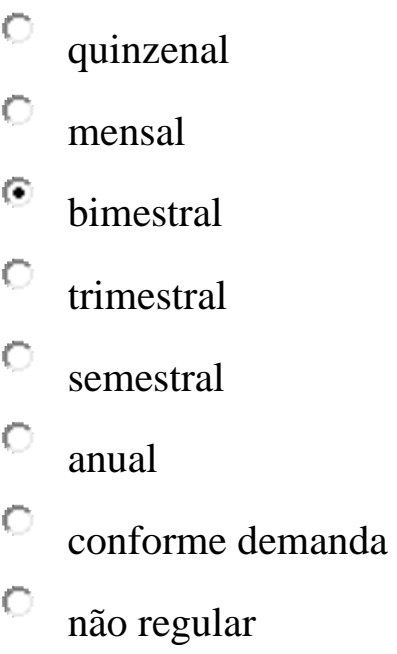

20) O CAE acompanhou os processos de compras dos gêneros alimentícios?
(6) Sim
Não

21) O CAE comunicou/denunciou alguma irregularidade da execução do PNAE?<smiles></smiles>

22) O CAE tem conhecimento da existência de outros programas que atuem de forma integrada com o PNAE no município/estado/DF?
Sim
(*) Não
Não sabe

Houve algum prejuízo financeiro?

Sim

( Não 